\title{
THE DISTINQUISHING FEATURES OF THE FAULTS IN THE PLATFORM COVER: RESULTS OF THE APPLICATION OF TECTONOPHYSICAL APPROACH TO THE STUDY OF THE TAMBEY HYDROCARBON DEPOSIT (YAMAL PENINSULAR)
}

\author{
K.Zh. Seminsky $\oplus^{1 凶}{ }^{\circledR}$, Yu.P. Burzunova ${ }^{1}{ }^{1}$, A.I. Miroshnichenko ${ }^{1}$, S.A. Bornyakov ${ }^{1}{ }^{1}$, A.A. Nezhdanov ${ }^{3}$, \\ A.V. Ershov ${ }^{3}$, A.S. Smirnov ${ }^{3}$, I.V. Buddo ${ }^{2}{ }^{2}$, A.K. Seminsky ${ }^{1}{ }^{1}$, A.S. Cheremnykh ${ }^{1}{ }^{1}$, I.V. Kachinskas ${ }^{3}$
}

\author{
${ }^{1}$ Institute of the Earth's Crust, Siberian Branch of the Russian Academy of Sciences, 128 Lermontov St, Irkutsk 664033, \\ Russia \\ ${ }^{2}$ SIGMA-GEO LLC, 6 Zvezdinskaya St, Irkutsk 664039, Russia \\ ${ }^{3}$ Gazprom VNIIGAZ LLC, 15-1 Proyektiruyemy Dr № 5537, Razvilka 142717, Moscow Region, Russia
}

ABSTRACT. The study was aimed to identify the features of the formation and regularities of manifestation of faults in the platform environment applying the tectonophysical approach to the study of the structure of the Tambey hydrocarbon deposit (northern Yamal), largest in the West Siberia. Such research is important in the oil and gas industry at the present stage of transition from the exploitation of declining unique and large deposits to exploration and exploitation of deposits of complex structure. The tectonophysical approach was applied consistently in three levels of research. Initial consideration was given to regular trends in the structure of the platform cover in the context of general tectonophysical ideas of disjunctive faults, their inner structure and formation features. Then, the identification of a network of large fault zones has been done at the regional level for the northern Yamal on the basis of the lineament analysis of the relief and optical modeling, three main stages of its formation have been reconstructed, and there have been identified the features of the state of stress, among other factors determining the Tambey deposit contours in three areas - western and northern Tambey and Tasyi. Finally, based on tectonophysical interpretation of 3D seismic attribute analysis data and elastoplastic modeling experiment results, for the northern Tambey area at the local level there were identified the faults zones, the features of their structures in rheologically stratified unit, and the paragenetic relationship with the regional-level structures.

The study has shown that the structure of the sedimentary cover, whose formation is tectonically influenced by the adjacent mobile belts, is zone-block. It reflects the zone-block structure of the basement, though, in contrast, is not represented by narrow main-fault planes ( $1^{\text {st }}$-order faults). The blocks in the cover contact along rather wide zones, the inner structure of which corresponds to the early stages of faulting and is represented by a dense network of the $2^{\text {nd }}$-order fractures and faults. The fault zones are characterized by an inhomogeneous - segment - structure which is determined by an initially irregular development of deformations and complicated by rheological stratification of the sedimentary cover. Fault segments in relatively brittle rocks (sandstones) are composed of long faults whereas in more ductile (clayey) varieties these are wide parts of concentration of small faults and fractures.

A style of the zone-block structure and the types of dynamic environments of its formation might be specific in different regions. The application of tectonophysical approach to the analysis of the geological-geophysical information, obtained for certain deposits, will make it possible to identify the structural conditions for hydrocarbon accumulation and migration in the sedimentary cover which is essential to choose an effective method of deposit exploitation.

KEYWORDS: tectonophysical approach; hydrocarbon deposit; fault zone; block; state of stress; sedimentary cover; 3D seismic survey; physical modeling

FUNDING: Experimental studies on regularities of manifestation of faults in an inhomogeneous environment correspond to the government contract theme "Recent geodynamics, mechanisms for destruction of the lithosphere, and geological hazards in Central Asia" (FWEF-2021-0009). The research activities involved work equipment of CCU "Geodynamics and Geochronology" at the Institute of the Earth's Crust SB RAS under the grant 075-15-2021-682.

\section{RESEARCH ARTICLE}

FOR CITATION: Seminsky K.Zh., Burzunova Yu.P., Miroshnichenko A.I., Bornyakov S.A., Nezhdanov A.A., Ershov A.V.,. Smirnov A.S, Buddo I.V., Seminsky A.K., Cheremnykh A.S., Kachinskas I.V., 2021. The distinquishing features of the faults in the platform cover: results of the application of tectonophysical approach to the study of the Tambey hydrocarbon deposit (Yamal Peninsular). Geodynamics \& Tectonophysics 12 (4), 969-991. doi:10.5800/GT-2021-12-4-0566 


\title{
СПЕЦИФИКА ПРОЯВЛЕНИЯ РАЗЛОМОВ В ПЛАТФОРМЕННОМ ЧЕХЛЕ: РЕЗУЛЬТАТЫ ПРИМЕНЕНИЯ ТЕКТОНОФИЗИЧЕСКОГО ПОДХОДА К ИССЛЕДОВАНИЮ ТАМБЕЙСКОГО МЕСТОРОЖДЕНИЯ УГЛЕВОДОРОДОВ (П-ОВ ЯМАЛ)
}

\author{
К.Ж. Семинский ${ }^{1}$, Ю.П. Бурзунова ${ }^{1}$, А.И. Мирошниченко ${ }^{1}$, С.А. Борняков ${ }^{1}$, А.А. Нежданов ${ }^{3}$, А.В. Ершов ${ }^{3}$, \\ А.С. Смирнов ${ }^{3}$, И.В. Буддо ${ }^{2}$, А.К. Семинский ${ }^{1}$, А.С. Черемных ${ }^{1}$, И.В. Качинскас ${ }^{3}$
}

\author{
${ }^{1}$ Институт земной коры СО РАН, 664033, Иркутск, ул. Лермонтова, 128, Россия \\ ${ }^{2} 000$ «СИГМА-ГЕО», 664039, Иркутск, ул. Звездинская, 6, Россия \\ ${ }^{3} 000$ «Газпром ВНИИГАЗ», 142717, Московская область, п. Развилка, пр-д Проектируемый № 5537, 15/1, Россия
}

\begin{abstract}
АНнотАЦИЯ. Целью проведенного исследования было установить особенности формирования и закономерности проявления разломов в платформенных условиях на основе применения тектонофизического подхода к исследованию структуры крупнейшего в Западной Сибири Тамбейского месторождения углеводородного сырья (Северный Ямал). Подобные исследования актуальны для нефтегазовой отрасли на современном этапе перехода от разработки истощающихся уникальных и крупных месторождений к разведке и эксплуатации залежей со сложной структурой. Тектонофизический подход был реализован последовательно в рамках трех уровней исследования. Вначале закономерности разломного строения платформенного чехла были рассмотрены с точки зрения общих представлений тектонофизики о дизъюнктивных структурах, их внутреннем строении и особенностях формирования. Затем на региональном уровне для Северного Ямала с использованием линеаментного анализа рельефа и оптического моделирования была выделена сеть крупных разломных зон, реконструированы три главных этапа ее формирования, выявлены особенности напряженного состояния, которые наряду с другими факторами определяют контуры Тамбейского месторождения на трех участках: Западно-Тамбейском, Северо-Тамбейском и Тасийском. Далее для Северо-Тамбейской площади на локальном уровне посредством тектонофизической интерпретации данных атрибутного анализа куба сейсмической информации и результатов экспериментов на упругопластичных моделях были выявлены разломные зоны, особенности их строения в реологически расслоенной толще, а также парагенетическая связь со структурами регионального уровня.

В итоге проведенного исследования показано, что структура осадочного чехла, формирующаяся вследствие тектонического воздействия со стороны смежных подвижных поясов, является зонно-блоковой. Она отражает разломно-блоковую структуру фундамента, но в отличие от нее не представлена узкими сместителями магистрального типа (разрывами 1-го порядка). Блоки в чехле контактируют по достаточно широким зонам, внутреннее строение которых соответствует ранним стадиям разломообразования и представлено густой сетью трещин и разрывов 2-го порядка. Разломные зоны характеризуются неоднородным - сегментным - строением, что определяется изначально неравномерным развитием деформаций и осложняется реологической расслоенностью осадочного чехла. Сегменты разлома в сравнительно хрупких породах (песчаники) состоят из протяженных разрывов, а в более податливых (глинистых) разностях это широкие участки сгущения мелких нарушений и трещин.

Стиль зонно-блоковой структуры и типы динамических обстановок ее формирования должны быть специфичны в разных регионах. Использование тектонофизического подхода к анализу полученной для конкретных месторождений геолого-геофизической информации позволит установить структурные условия накопления и миграции углеводородов в осадочном чехле, что имеет принципиальное значение для выбора эффективной методики разработки их залежей.
\end{abstract}

КЛЮЧЕВЫЕ СЛОВА: тектонофизический подход; месторождение углеводородов; разломная зона; блок; напряженное состояние; осадочный чехол; 3D сейсморазведка; физическое моделирование

ФИНАНСИРОВАНИЕ: Экспериментальные исследования, касающиеся общих закономерностей проявления разломов в неоднородной среде, соответствуют тематике государственного задания «Современная геодинамика, механизмы деструкции литосферы и опасные геологические процессы в Центральной Aзии» (№ FWEF-20210009). В работе задействовалось оборудование ЦКП «Геодинамика и геохронология» Института земной коры СО РАН в рамках гранта № 075-15-2021-682.

\section{1. ВВЕДЕНИЕ}

Разработка трудноизвлекаемых запасов углеводородного сырья в настоящее время становится одним из главных приоритетов освоения нефтегазового комплекса России [Kontorovich, Eder, 2015]. Как следствие, выявление закономерностей строения и напряженного состояния осадочного чехла имеет определяющее значение для достоверного подсчета запасов, а также для повышения эффективности поисков и разведки продуктивных залежей на месторождениях углеводородов (УВ) со сложной структурой. При этом ключевой проблемой является выбор мест безаварийного бурения разведочных и эксплуатационных скважин в породном массиве, который характеризуется неоднородным напряженно-деформированным состоянием вследствие наличия зон повышенной нарушенности и участков аномальных пластовых давлений. Задача их выявления и достоверного картирования приобретает 
все большую актуальность по мере падающей добычи на уникальных и крупных месторождениях.

В этих условиях особое значение имеют методы тектонофизики, которые позволяют на основе анализа комплекса геолого-геофизических данных выделять разломные зоны, реконструировать напряженное состояние породного массива и определять механизмы его деструкции под действием сил тектонической или гравитационной природы. Более того, в настоящее время на новом уровне сформировались предпосылки для эффективного исследования структуры месторождений УВ с применением тектонофизического подхода. С одной стороны, это связано с повышением детальности исследования недр за счет интенсивного развития технологии съемок (прежде всего, сейсморазведки) и создания банка кондиционных геофизических данных по многим лицензионным площадям. С другой стороны, тектонофизика достигла уровня, на котором полученные закономерности и технологии картирования разломных сетей и напряженного состояния недр могут быть эффективно применены в практике поисков и разведки УВ на месторождениях с трещинным или порово-трещинным типом коллекторов.

Целью данной статьи было применить тектонофизический подход для определения специфики формирования и закономерностей проявления разломов в платформенных условиях на примере крупнейшего в Западной Сибири Тамбейского месторождения углеводородного сырья.

Уникальные геолого-геофизические материалы (в т.ч. данные 3D сейсморазведки), полученные при изучении месторождения, являются кондиционной базой для выделения разрывных нарушений на основе методик, широко используемых в мировой практике. Вместе с тем применение современных подходов не всегда позволяет получить полную картину нарушенности реологически расслоенного осадочного чехла, так как во многих платформенных регионах воздействие тектонических сил было недостаточно продолжительным или интенсивным для возникновения разломов, смещающих маркирующие горизонты.

Подобная ситуация характерна для Тамбейского месторождения (Северный Ямал), которое разведывается на трех лицензионных участках - Западно-Тамбейском (ЗТУ), Северо-Тамбейском (СТУ) и Тасийском (ТУ), выделенных, исходя из общих контуров и специфики залежей (рис. 1). Особенности разломообразования в осадочном чехле рассматриваются ниже на примере данной территории в рамках тектонофизического подхода, реализованного на трех уровнях.

Вначале доказательства существования разломов в платформенном чехле анализируются в соответствии с общими понятиями тектонофизики о дизъюнктивных структурах и особенностях их формирования (раздел 2). Далее в разделе 3 рассматриваются результаты тектонофизического анализа разломных зон территории Северного Ямала, и, наконец, в разделе 4 представлены закономерности разрывной структуры Северо-

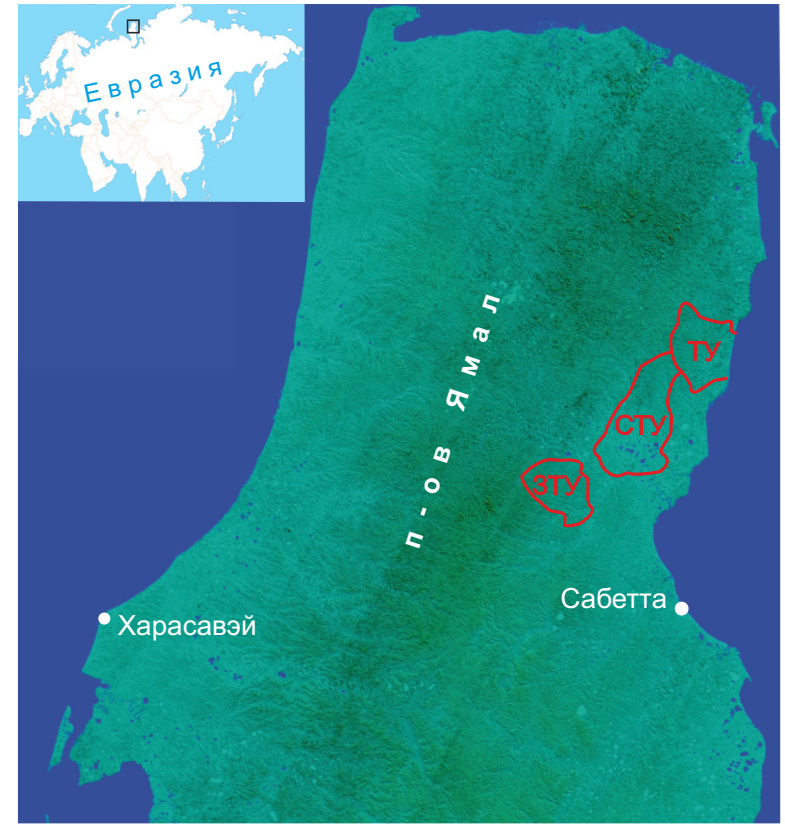

Рис. 1. Контуры главных залежей Тамбейского месторождения в пределах ЗТУ, СТУ и ТУ на севере п-ва Ямал.

Fig. 1. Contours of major deposits in the Tambey field within WT, NT and T areas in the northern Yamal Peninsular.

Тамбейского участка, полученные в итоге тектонофизической интерпретации данных атрибутного анализа куба сейсмической информации и результатов экспериментов на упругопластичных моделях. Краткая характеристика методов исследований, реализованных на региональном и локальном уровне, приведена в каждом из посвященных им разделов.

\section{2. ТЕКТОНОФИЗИЧЕСКИЙ ПОДХОД К КАРТИРОВАНИЮ РАЗЛОМНЫХ СТРУКТУР И ОСОБЕННОСТЕЙ ИХ ВНУТРЕННЕГО СТРОЕНИЯ В РЕОЛОГИЧЕСКИ НЕОДНОРОДНЫХ ОСАДОЧНЫХ КОМПЛЕКСАХ}

В тектонофизике как в науке о механизмах формирования деформационных структур земной коры понятие «разлом» в отличие от структурной геологии трактуется более широко [Sherman et al., 1983; Seminsky, 2003]. Это не только узкая полоса тектонитов магистрального сместителя (разрыв 1-го порядка), а существенно большая по размерам зона распространения разрывов 2-го порядка, образующихся на трех главных стадиях разломообразования (рис. 2, а).

На ранней дизъюнктивной стадии (рис. 2, a-I) имеет место широкая зона сравнительно мелких опережающих разрывов, которую в отечественной практике обычно называют зоной повышенной трещиноватости или зоной скрытого разлома фундамента [Radkevich et al., 1956; Rats, Chernyshev, 1970; Khrenov et al., 1977; Makarov, Shchukin, 1979]. За рубежом для обозначения подобных структур (рис. 3) часто используется термин «коридор трещин» [Ozkaya, Richard, 2006; Gabrielsen, Braathen, 2014; Lamarche et al., 2018; Souque et al., 2019]. 
На поздней дизъюнктивной стадии (см. рис. 2, а-II) разлом выражен зоной распространения опережающих разрывов, представленных небольшими сегментами магистрального сместителя, между которыми располагаются интенсивно нарушенные области их сочленения друг с другом. Разлом на дизъюнктивной стадии полного разрушения (см. рис. 2, а-III) представлен единым магистральным сместителем и разрывами оперения. В осадочном чехле платформ разломы представлены ранней или, реже, поздней стадией развития, так как интенсивность или продолжительность однонаправленного воздействия обычно недостаточна для формирования магистрального сместителя.
Внутреннее строение разломной зоны, независимо от стадии развития, характеризуется неравномерной нарушенностью в продольном и поперечном направлении (см. рис. 2, а). Она имеет место даже в однородном субстрате, поскольку отражает фундаментальное свойство распределения деформаций. Очевидно, что реологическая (структурно-механическая) расслоенность, свойственная осадочному чехлу, будет вносить свой вклад в усложнение внутреннего строения разломной зоны.

Происхождение разрывной сети осадочного чехла обусловлено в первую очередь тектоническим давлением со стороны смежных мобильных поясов. Об этом (a)

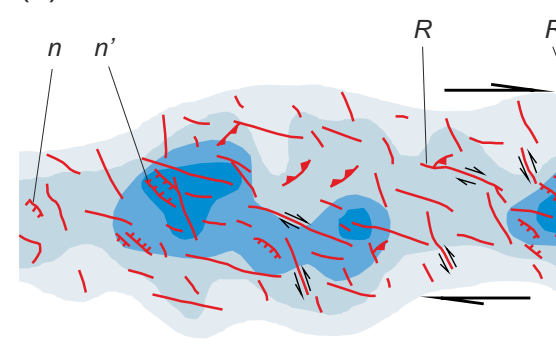

Ранняя дизъюнктивная стадия - I

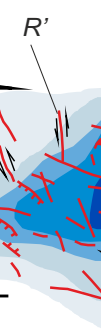

(б)

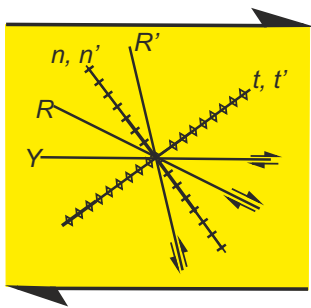

(8)

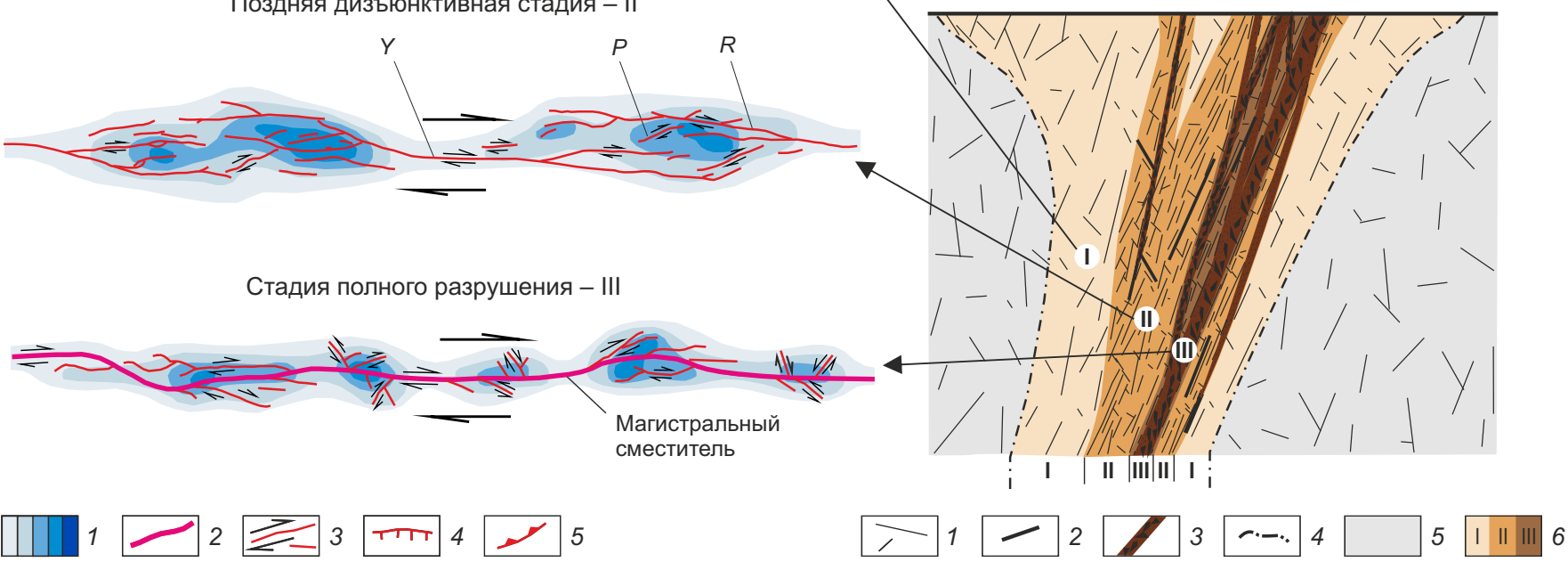

Рис. 2. Структура разломной зоны (на примере правого сдвига) [Seminsky, 2014, 2015].

$(a)$ - строение разломной зоны на трех главных стадиях развития: 1 - участки с различным количеством разрывов в единице площади; 2 - магистральный сместитель (разрыв 1-го порядка); 3-5 - сдвиги (3), сбросы (4) и надвиги (5) 2-го порядка. Латинские буквы - разнотипные разрывы 2-го порядка (R', R, n', n, t', t, P) и магистральный сместитель 1-го порядка (Y); (б) - эталонный парагенезис (трафарет) разрывов 2-го порядка для правосдвиговой зоны, который представлен в плоском варианте, позволяющем проводить анализ роза-диаграмм простираний разрывных нарушений природной сети; (в) - принципиальная схема поперечной зональности разлома, прошедшего в своем развитии все три стадии разрывообразования: 1 трещиноватость; 2 - крупные трещины; 3 - сместитель, заполненный тектонитами; 4 - внешняя граница разломной зоны; 5 - слабонарушенный породный массив; 6 - главные элементы внутреннего строения разломной зоны, сформировавшиеся на разных стадиях разрывообразования.

Fig. 2. Fault zone structure (by the example of the dextral sttrike-skip fautl) [Seminsky, 2014, 2015].

(a) - fault zone structure at three main stages of development: 1 - areas with a different number of faults per area unit; 2 - major fault plain (1st-order fault); 3-5 - strike-slip faults (3), normal faults (4) and thrusts (5) of the $2^{\text {nd }}$ order. Latin letters stand for different-type $2^{\text {nd }}$-order faults ( R', R, n', n, t', t, P) and main fault plane of the $1^{\text {st }}$ order (Y); ( $\sigma$ ) - idealized paragenesis (pattern) of the $2^{\text {nd }}$-order faults for the dextral strike-slip fault zone represented by flat pattern which allows analyzing rose diagrams of the fault strikes in the natural network; ( 8 ) - a principal scheme of transverse zonality of the fault experienced all three stages of development: 1 - fracturing; 2 - large fractures; 3 - fault plane filled with tectonites; 4 - external boundary of the fault zone; 5 - weakly disturbed natural massif; 6 - main elements of the inner structure of the fault zone formed at different stages of faulting. 
(a)

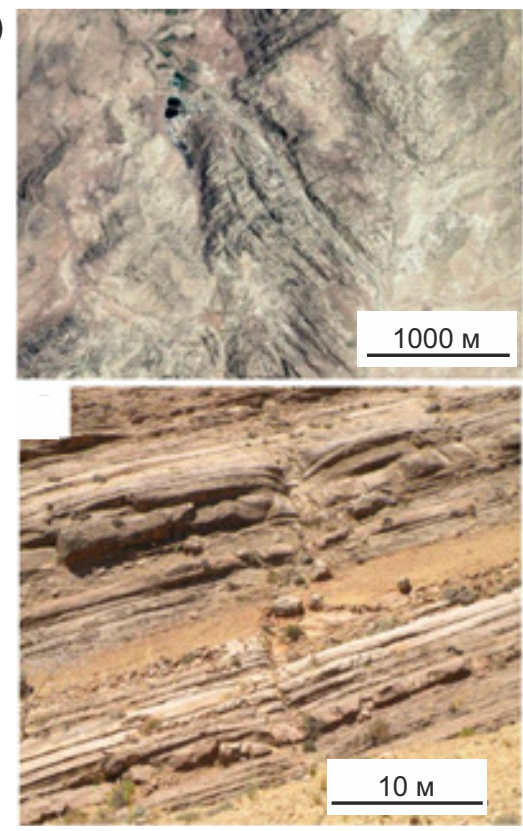

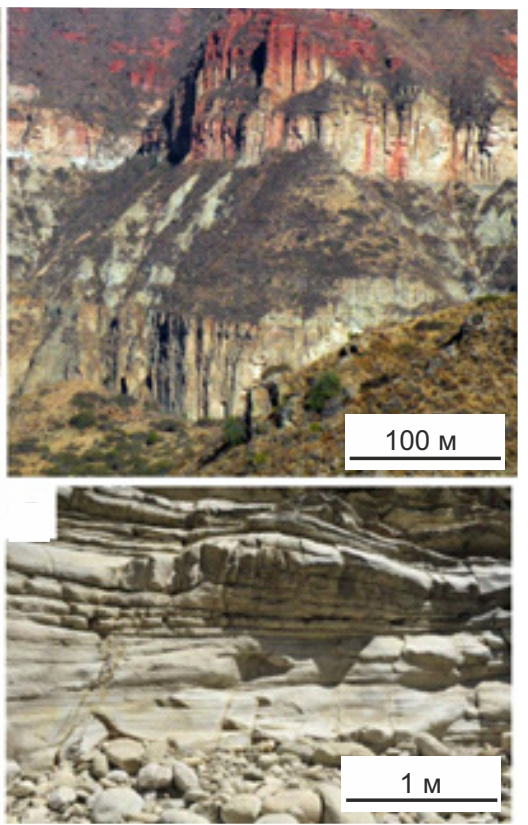

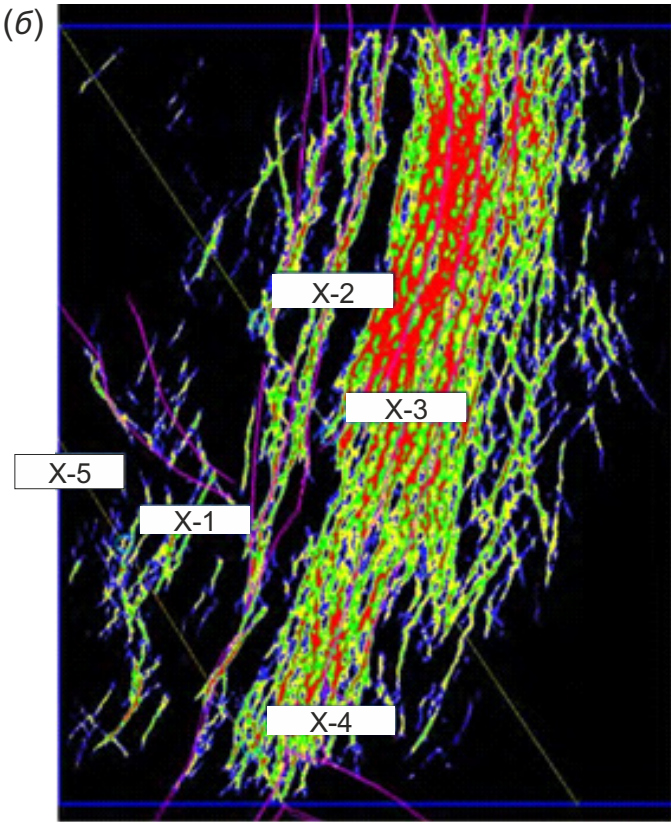

Рис. 3. Разномасштабные «коридоры трещин» на поверхности (a) [Lamarche et al., 2018] и пример отражения подобных структур на глубине - в атрибутах сейсмической записи (б) [Singh et al., 2008].

Fig. 3. Different-scale "fracture corridors" on the surface (a) [Lamarche et al., 2018] and an example of reflection of similar structures at a depth - in seismic attributes (б) [Singh et al., 2008].

свидетельствуют исследования платформенной трещиноватости [Leonov, 1995; Hancock, Engelder, 1989; Engelder, Gross, 1993; Seminsky et al., 2018], формирование которой даже при диагенезе редко происходит без так называемого влияния «тектонической рамы» [Chernyshev, 1983]. Для территории Ямала трансформация на платформу тектонических напряжений, интенсивно проявляющихся в пределах пограничных подвижных поясов, отмечается во многих публикациях [Nezhdanov, 2004; Astafiev, Skorobogatov, 2006; Sobornov, Yakubchuk, 2006; Kontorovich, 2009; Podurushin, 2011, 2014; Kushnir, 2016; Kurkin, 2019].

Таким образом, современные представления тектонофизики о нарушенности пород платформенного чехла (в т.ч. и на Ямале) априори свидетельствуют о том, что он имеет неоднородную структуру, которая обусловлена тектоническим влиянием со стороны смежных подвижных поясов. Эта структура должна быть представлена слабодислоцированными участками блоками, а также зонами с повышенной плотностью трещин и более крупных разрывов. Строение одной и той же разрывной зоны на отдельных отрезках может отвечать ранней или поздней стадии разломообразования, что связано с изначально неоднородным распределением деформаций и может усугубляться реологической расслоенностью осадочного чехла. Как следствие, компетентность подобного массива по отношению к накоплению, сохранности залежей и миграции углеводородов различна, что обусловливает практическую значимость исследования разломной структуры в районах локализации нефтегазовых месторождений.

\section{3. РЕГИОНАЛЬНЫЙ УРОВЕНЬ: РАЗЛОМНАЯ СТРУКТУРА СЕВЕРНОГО ЯМАЛА И ЭТАПЫ ЕЕ ФОРМИРОВАНИЯ ПО ДАННЫМ ЛИНЕАМЕНТНОГО АНАЛИЗА РЕЛЬЕФА И ТЕКТОНОФИЗИЧЕСКОГО МОДЕЛИРОВАНИЯ}

3.1. Результаты линеаментного анализа рельефа

Изучение в региональном масштабе зон повышенной дислоцированности осадочного чехла для слабообнаженной территории Ямала было проведено на базе линеаментного анализа. Методика выявления разломных зон состояла в выделении по цифровой модели Aster GDEM2 (см. рис. 1) линеаментов - прямолинейных или слабоизогнутых уступов, отрезков речных долин и пр., происхождение которых связано с наличием в породном массиве тектонических нарушений.

Как видно из рис. 4, а, б, спрямленные элементы рельефа на изучаемой территории группируются в широкие зоны, простирание которых соответствует ориентации наиболее длинных из составляющих их линеаментов. Даже если не отождествлять все выделенные линеаменты с тектоническими разрывами, зоны их повышенной плотности с позиций тектонофизики следует считать разломными. Это дизъюнктивы, внутреннее строение которых соответствует ранним стадиям развития и выражено в чехле сетью опережающих разрывов 2-го порядка (см. рис. 2, a-I, а-II). Магистральный сместитель (разрыв 1-го порядка) у подобных структур не сформировался вследствие слабой тектонической активности платформенного региона.

Поскольку зоны ограничивают менее дислоцированные блоки (рис. 4, а, б), структуру верхней части осадочного чехла на Северном Ямале можно считать 
зонно-блоковой [Seminsky, 2008]. Ей свойственна иерархическая соподчиненность структурных элементов: протяженность, ширина и пространственные взаимоотношения зон позволяют разделить их в первом приближении на три масштабных ранга. Это 2, 3 и 4-й ранги, поскольку в качестве наиболее крупной структуры 1-го ранга на юге изучаемой площади выделяется широтная зона (рис. 4, б), в пределах которой имеет место система крупных аналогично простирающихся разломов [Рodurushin, 2011]. Оставшаяся часть полуострова представляет блок 1-го ранга с существенно отличающимся строением сети более мелких разломных зон (рис. 4, а).
С целью реконструкции динамических обстановок (полей напряжений) формирования зонно-блоковой структуры Северного Ямала для зоны и блока 1-го ранга был применен парагенетический анализ в авторской модификации [Seminsky, 2014, 2015]. Он отличается от других разновидностей метода типами парагенезисов разрывов 2-го порядка, принимаемых в качестве исходных для реконструкции напряженного состояния. В данном случае это полные парагенезисы, являющиеся результатом постадийного разломообразования (см. рис. 2, а, б), в процессе которого происходит закономерная смена стресс-тензоров 2-го порядка.

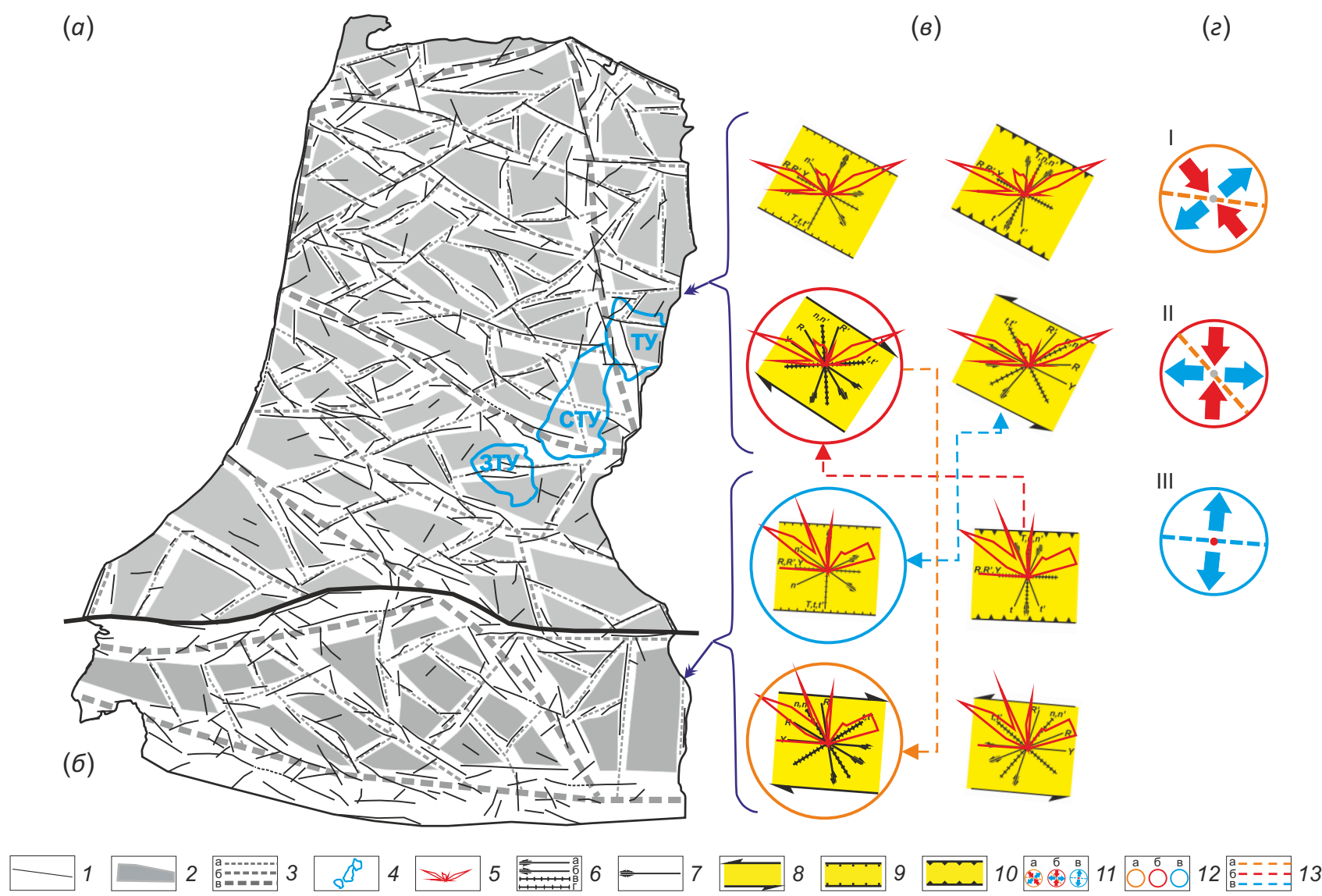

Рис. 4. Схемы разломных зон для структур 1-го ранга ( $(a)$ - блока и (б) - зоны) на Северном Ямале и динамические обстановки их формирования (2) по данным парагенетического анализа (в).

1 - линеаменты рельефа, выделенные по детализированной модели рельефа; 2 - блоки; 3 - оси зон 4-го (а), 3-го (б) или 2-го (в) масштабного ранга; 4 - контуры залежей в пределах трех участков; 5 - роза-диаграммы осей разломных зон; 6-10 - элементы эталонных парагенезисов разрывов в разломных зонах сброса, взброса, правого и левого сдвига, согласно [Seminsky, 2014]: 6-7 - разнотипные разрывы 2-го порядка в парагенезисах зон скалывания, 8-10 - зоны сдвига (8), сброса (9) и взброса (10) 1-го порядка; 11 - разнотипные тензоры напряжений (а-I, б-II и в-III), реконструированные для зоны и блока в целом; 12-13 - решения (12) и их парагенетические связи (13), установленные для трех главных динамических обстановок (а-I, б-II и в-III).

Fig. 4. Schemes of fault zones for the $1^{\text {st }}$-rank structures $((a)$ - block and (б) - zone) in the northern Yamal and dynamic settings of their formation (2) from the data of paragenetic analysis ( $(8)$.

1 - lineaments of relief identified from the detailed relief model; 2 - blocks; 3 - axes of zones of the $4^{\text {th }}\left(\right.$ (a), $3^{\text {rd }}\left(\right.$ (б) or $2^{\text {nd }}($ в) scale rank; 4 - deposit contours within three areas; 5 - rose diagrams of fault zone axes; 6 - elements of idealized paragenesis of faults in the normal, reverse and dextral and sinistral strike-slip fault zones after [Seminsky, 2014]: 6-7 - different-type $2^{\text {nd }}$-order faults in parageneses of shear zones, 8-10 - strike-slip (8), reverse (9) and normal fault (10) zones of the $1^{\text {st }}$ order; different-type stress tensors (a-I, 6-II and B-III), reconstructed for zone and for block as a whole; 12-13 - solutions (12) and their paragenetic relationships (13) identified for three main dynamic environments (a-I, б-II and B-III). 
Метод заключается в последовательном сопоставлении эталонных трафаретов сбросовой, взбросовой, право- и левосдвиговой зон с диаграммой природной разрывной сети. При этом трафареты ориентируются согласно направлению главного луча диаграммы или в соответствии с простиранием системы, представленной наиболее крупными разломами. Удовлетворительное совпадение большинства природных разрывных направлений с системами одной из эталонных диаграмм позволяет получить решение о его деформации в разломной зоне с определенной кинематикой и, соответственно, о типе стресс-тензора. Для оставшихся на диаграмме разрывных направлений подбирается следующий трафарет вплоть до того момента, когда происхождение всех природных разрывных систем не будет объяснено воздействием определенного поля напряжений. Обычно таких решений бывает 2-4, что свидетельствует о деформации горных пород на отдельных этапах тектогенеза, каждому из которых соответствует одна из реконструированных динамических обстановок.

Решения парагенетического анализа, несмотря на отличия для блока и зоны в деталях (рис. 4, в), позволили выделить главные поля напряжений, предопределившие формирование зонно-блоковой структуры
Северного Ямала (рис. 4, г). Их три: I - поле сдвига с северо-западной ориентацией оси сжатия и северо-восточной - оси растяжения; II - поле сдвига с субмеридиональной ориентировкой оси сжатия и субширотной - оси растяжения; III - поле растяжения в субмеридиональном направлении. При этом поле I в чистом виде (1-й порядок) проявлено в зоне 1-го ранга, по которой происходил правый сдвиг (см. оранжевый пунктир на рис. 4, в), тогда как в блоке ему соответствуют решения правого сдвига по северо-западным зонам, сформировавшимся во 2-м порядке как правосторонние R-сколы. Поле II в 1-м порядке характерно для блока, так как во 2-м порядке его поддерживает решение меридионального сжатия для зоны (см. красный пунктир на рис. 4, в). Поле III в чистом виде (1-й порядок) проявлено в зоне 1-го ранга, являющейся в данном случае сбросовой, тогда как в блоке ему соответствует левый сдвиг по северозападной системе (см. синий пунктир на рис. 4, в).

На рис. 5 разным цветом показаны те зоны, которые могли быть активны в каждом из трех выявленных полей напряжений регионального уровня, согласно эталонным парагенезисам разрывов, соответствующим этим динамическим обстановкам. Кинематика движений является прогнозной, однако она отчетливо свидетельствует о разломном контроле залежей
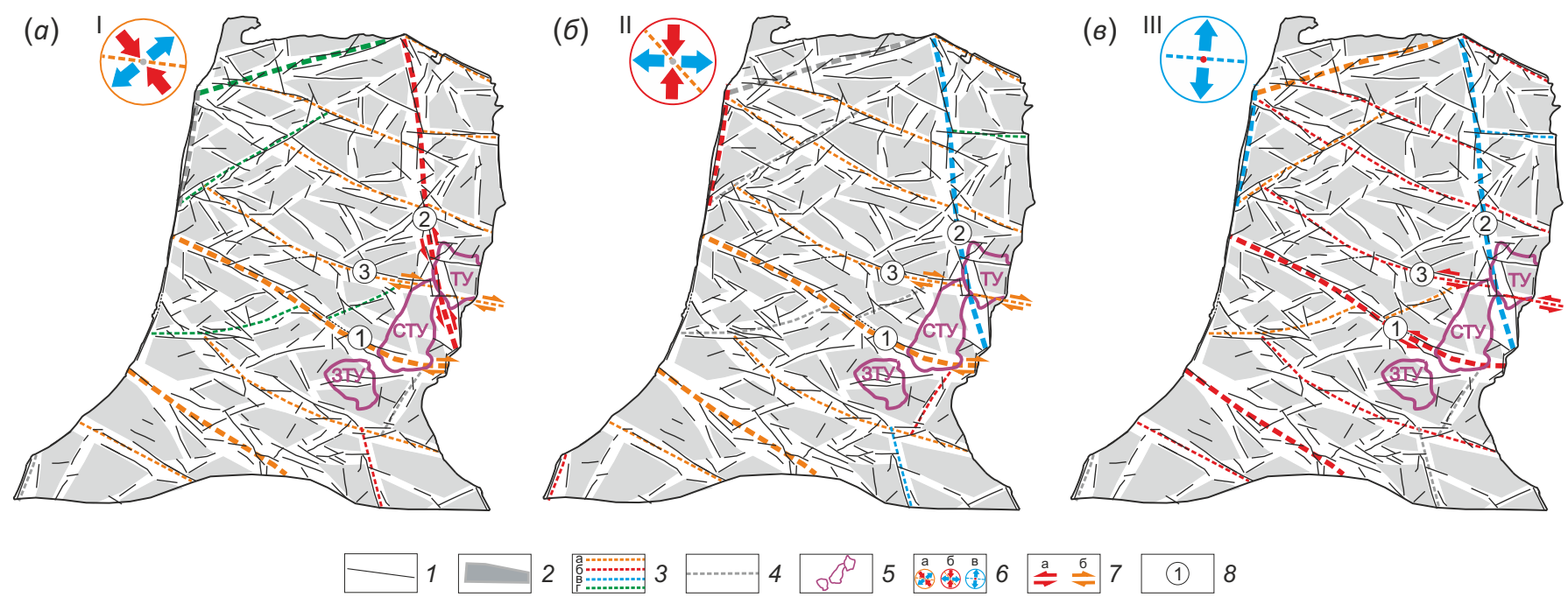

Рис. 5. Схемы крупных разломных зон, активных в пределах блока Северного Ямала на трех этапах тектогенеза (a, 6 , 8$)$. 1 - линеаменты рельефа; 2 - блоки; 3 - оси крупных разломных зон (2-й и 3-й ранги), активизированных в показанной на схеме динамической обстановке как правые сдвиги (а), левые сдвиги (б), сбросы (в) или взбросы (г); 4 - оси крупных разломных зон (2-й и 3-й ранги), не активных в показанной на схеме динамической обстановке; 5 - контуры залежей в пределах трех участков; 6 - стресс-тензоры, соответствующие трем этапам тектогенеза: а - обстановка сдвига с северо-западной осью сжатия и северо-восточной осью растяжения, б - обстановка сдвига с субмеридиональной осью сжатия и субширотной осью растяжения, в - обстановка растяжения в субмеридиональном направлении; 7 - направления скольжения блоков по левосдвиговым (а) и правосдвиговым зонам в окрестностях месторождения (б); 8 - номера разломов, описанных в тексте.

Fig. 5. Schemes of large fault zones which are active within the northern Yamal block at three stages of tectogenesis $(a, 6,8)$. 1 - lineaments of relief; 2 - blocks; 3 - axes of large fault zones ( $2^{\text {nd }}$ and $3^{\text {rd }}$ ranks) activated in the schemed dynamic setting as dextral strike-slip faults (а), sinistral strike-slip faults (б), normal faults (в) or reverse faults (Г); 4 - axes of large fault zones ( $2^{\text {nd }}$ and $3^{\text {rd }}$ ranks) inactive in the schemed dynamic setting; 5 - deposit contours within three areas; 6 - stress tensors corresponding to three stages of tectogenesis: a - setting of strike-slip fault with a NW orientation of the compression axis and a NE orientation of the extension axis, $\sigma$ - setting of strike-slip fault with a submeridional orientation of the compression axis and sublatitudinal orientation of the extension axis, B - setting of submeridional extension; 7 - directions of block sliding along the sinistral (a) and dextral (б) strike-slip fault zones near the deposit; 8 - numbers of the faults described in the text. 
Тамбейского месторождения, если исходить из того, что углеводороды должны концентрироваться в пределах областей с меньшим давлением [Sim, 2013]. В данном случае им будут соответствовать участки растяжения пород осадочного чехла, к которым относятся, во-первых, квадранты растяжения в узлах сочленения правых и левых сдвигов и, во-вторых, сбросовые зоны.

Судя по размерам месторождения, локализация основных залежей в его пределах должна контролироваться разломными зонами 2 и 3-го ранга. На ЗападноТамбейском участке, отличающемся типом УВ (нефть и газоконденсат), месторождение принадлежит к центральной части блока, располагаясь на удалении от его разломных границ. В противоположность этому контуры месторождения в пределах Северо-Тамбейского и Тасийского участков определяются сочленениями трех разломных зон. Северная часть залежей на СТУ и весь ТУ располагаются в узле пересечения зон 2 и 3 , причем в противоположных квадрантах, которым в динамической обстановке I (рис. 5, а), судя по кинематике сдвиговых перемещений, свойственны условия растяжения. Характерно, что южная часть залежей на СТУ размещается западнее, т.е. закономерно не распространяется в северо-западный квадрант узла пересечения зон 1 и 2, где в динамической обстановке I имеет место сжатие.

Подобные условия для накопления углеводородов в принципе характерны и для обстановки II (рис. 5, б), так как по зонам 1 и 3 также происходят правосдвиговые перемещения блоков, а зона 2 развивается при растяжении. Однако господство для нее вертикальной компоненты перемещения (сброс) должно осложнять картину распределения участков сжатия и растяжения по глубине. Наконец, для динамической обстановки III (рис. 5, в) в рассмотренных узлах пересечения разломных зон 1, 2 и 3 имеет место реверс типа напряженного состояния, что не может способствовать формированию залежей в современных контурах месторождения на Северо-Тамбейском и Тасийском участках.

Таким образом, сеть разломных зон и их кинематика, установленная для трех этапов тектогенеза на основе тектонофизической обработки результатов линеаментного анализа, находятся в удовлетворительном соответствии с локализацией Тамбейского месторождения. Его контуры в пределах Северо-Тамбейского и Тасийского участков соответствуют благоприятным для накопления углеводородов участкам растяжения, которые имеют место при перемещениях по крупным разломным зонам в сдвиговых обстановках I и II. Эти выводы подтверждаются данными тектонофизического моделирования, которые позволяют оценить распределение напряжений в зонно-блоковой структуре Северного Ямала.

\section{2. Результаты тектонофизического моделирования}

Эксперименты, позволяющие получить наглядное распределение интенсивности напряжений в разломных зонах и блоках Северного Ямала, проводились на упругом оптически активном материале (желатин) по известной методике [Osokina, Tsvetkova, 1979]. Модель из желатина с разрезами, имитирующими крупные разломные зоны 2 и 3-го ранга (рис. 6, б), подвергалась силовому нагружению трех видов на установке ППД-300 (рис. 6, а). Авторским добавлением к методике являлось заполнение разрезов менее вязким (по отношению к основной модели) материалом, что позволяет оценить напряженное состояние разломных зон, строение которых соответствует ранней стадии развития.

Результатом эксперимента являются фотографии (рис. 6, в) и сделанные по ним схемы цветовых картин (рис. 6, г), получаемые при исследовании нагруженной модели в проходящем поляризованном свете. Они отражают распределение коэффициента интенсивности касательных напряжений $(K \tau)$ в модели с разрывами при силовом воздействии, которое соответствует трем выявленным для Северного Ямала динамическим обстановкам (см. I-III на рис. 6, г, д, е). При интерпретации результатов моделирования ключевым моментом являлась оценка распределений областей увеличения и уменьшения интенсивности напряжений относительно исходного уровня с $K \tau=1$ (коричневый цвет на рис. 6, г, д, е).

Не касаясь деталей полученных распределений, следует выделить различие в степени изменчивости $К \tau$ в зонах и блоках, характерное для всех трех обстановок (рис. 6, г, д, е). Напряжения, возникающие при нагружении в зонах, относятся либо к самому высокому $(K \tau=5)$, либо к самому низкому $(K \tau=0.5)$ уровню. В блоках спектр изменения интенсивности напряжений более широк, но они не доходят до экстремальных уровней $(0.7<K \tau<2.5)$. Как следствие, блоки более компетентны в плане концентрации углеводородов, тогда как зоны являются путями их миграции или экранами.

По уровню напряженного состояния блоки в целом более разуплотнены в сдвиговых обстановках I и II, тогда как в поле субмеридионального растяжения (III) они находятся под бо́льшим давлением (рис. 6, г, д, е). По напряженному состоянию зон обстановки I и III примерно подобны и отличаются от поля II, в котором большинство зон характеризуется низким уровнем напряжений.

В плане условий формирования скоплений углеводородов наиболее благоприятной является обстановка I: разуплотненные блоки окружены экранирующими разломными зонами (рис. 6, г). Подобные условия для блоков сохраняются и в обстановке II, но зоны во многих случаях являются каналами для миграции углеводородов, что способствует перераспределению залежей (рис. 6, д). Неблагоприятной для концентрации и сохранности полезного ископаемого является обстановка III (рис. 6, е), поскольку блоки в основном находятся в «зажатом» состоянии, что способствует выжиманию углеводородов в те смежные зоны, которые вследствие низкой интенсивности напряжений являются путями миграции углеводородов к дневной поверхности. 
Эти прогнозируемые по данным моделирования закономерности структурного контроля углеводородов подтверждаются локализацией основных залежей Тамбейского месторождения в пределах трех площадей (рис. 6, г, д, е). В обстановке I их местоположение практически совпадает с участками пониженных напряжений в блоках (поля желтого цвета на фото рис. 6, в, и схеме рис. 6, г), которые по всему периметру ограничиваются экранирующими зонами 1-4. Обстановка III (рис. 6, е) характеризуется почти противоположными условиями с напряженными блоками и проницаемыми зонами 2 и 3, что способствует разрушению залежей, по крайней мере, в пределах СТУ и ТУ.

Таким образом, тектонофизический подход к изучению сети разломных зон, выделенных на региональном уровне для Северного Ямала, позволил определить типы и характер пространственного проявления динамических обстановок, благоприятных для (a)

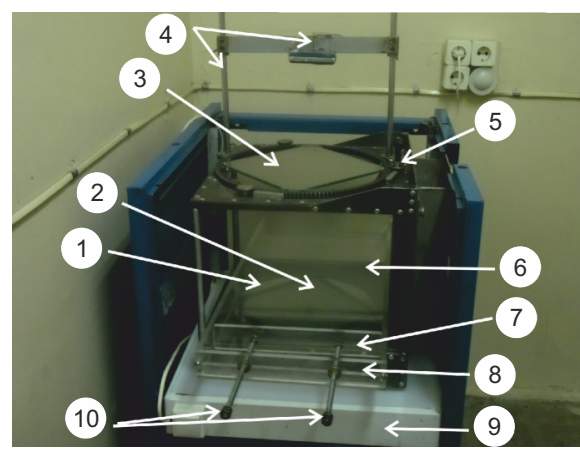

(б)

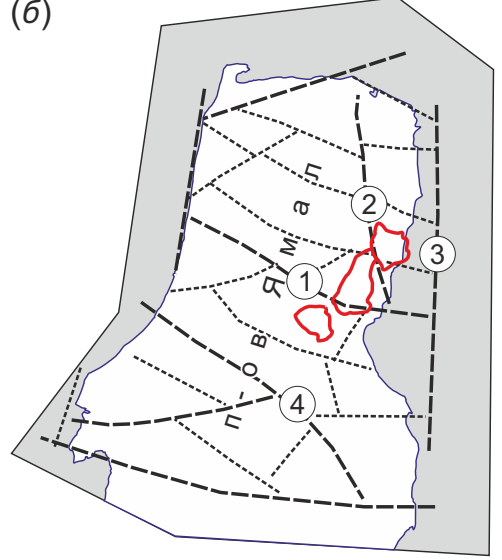

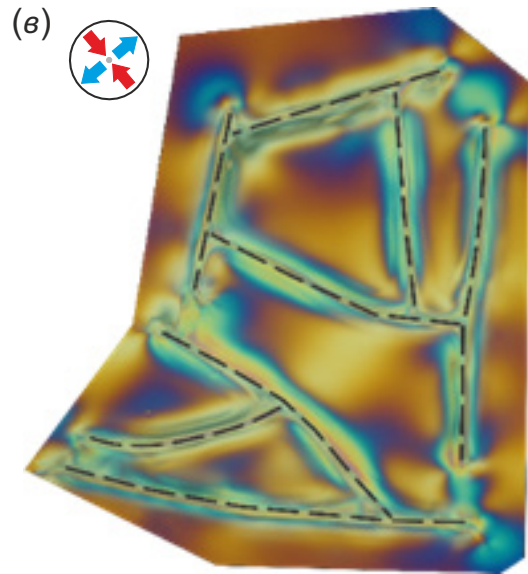

(2)

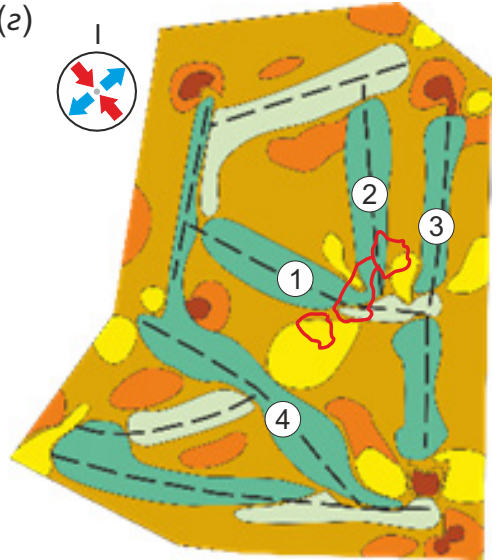

(d)

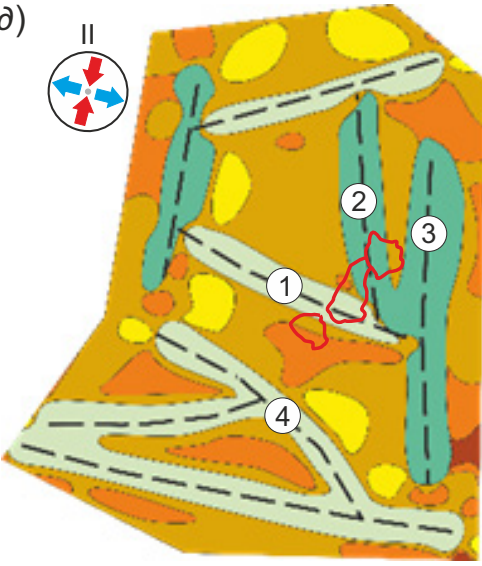

(e)

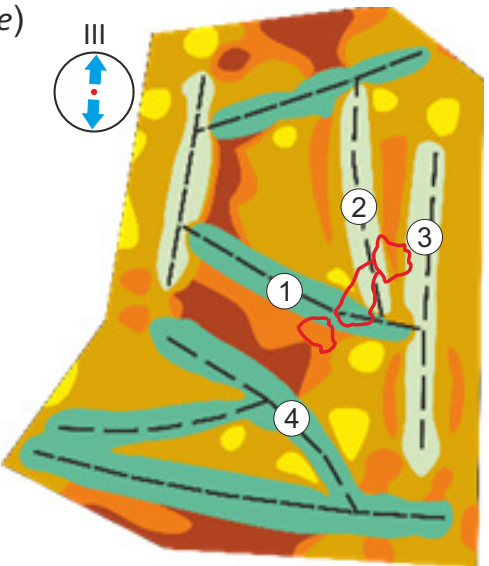

$\kappa \tau$

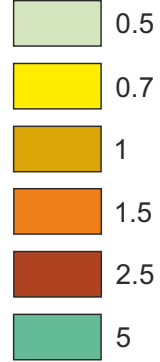

Рис. 6. Результаты моделирования полей напряжений в осадочной толще Северного Ямала на упругом оптически активном материале.

(a) - полярископ-поляриметр ППд-300 для исследования напряженного состояния в модели: 1 - модель из желатина; 2-3 поляроиды (2 - поляризатор, 3 - анализатор); 4 - штатив и крепление для фотокамеры; 5 - ручка для синхронного вращения поляроидов; 6-7 - штампы; 8 - плексигласовая ванна для размещения модели; 9 - осветитель (устройство для получения белого света); 10 - винты, регулирующие положение штампа, сжимающего модель. (б) - схема осей крупных разломных зон (2-й и 3-й ранги) Северного Ямала и контуры основных залежей Тамбейского месторождения. (в-e) - распределение коэффициента интенсивности касательных напряжений $(K \tau)$ на фото $(8)$ и схемах $(2-e)$, соответствующих трем динамическим обстановкам (I-III) формирования сети разломных зон (стресс-тензоры показаны слева от каждой схемы, шкала К $\tau$ приведена в правом нижнем углу рисунка; красные контуры - контуры залежей в пределах трех участков; номера в кружках - разломные зоны в их окрестностях).

Fig. 6. Results of modeling stress fields in the sedimentary series of the northern Yamal on elastic optically active material. (a) - PDD-300 polariscope-polarimeter to study the state of stress in the model: 1 - gelatin model; $2-3$ - polaroids (2 - polarizer, 3 analyzer); 4 - camera mount support; 5 - synchronous polaroid rotation handle; 6-7 - stamps; 8 - plexiglass bathtub for model placement; 9 - light source (white light-emitting device); 10 - screws adjusting the position of stamp which provides a model compression. (б) - scheme of the axes of large fault zones ( $2^{\text {nd }}$ and $3^{\text {rd }}$ ranks) of the northern Yamal and contours of major deposits of the Tambey field. $(8-e)$ - distribution of shearing stress intensity factor $(K \tau)$ on photos $(b)$ and schemes $(2-e)$, corresponding to three dynamic settings (I-III) of fault-zone network formation (stress tensors are shown on the left of each scheme, $K \tau$ scale is presented in the lower right angle of the figure; red contours are the deposit contours within three areas; circled numbers are the fault zones nearby). 
формирования залежей углеводородов. Расположение в их пределах основных залежей Тамбейского месторождения является свидетельством влияния разломной сети на распределение УВ и, как следствие, необходимости оценки структурного фактора на локальном уровне.

\section{4. ЛОКАЛЬНЫЙ УРОВЕНЬ: РАЗЛОМНЫЕ ЗОНЫ СЕВЕРО-ТАМБЕЙСКОГО УЧАСТКА, ПО ДАННЫМ ТЕКТОНОФИЗИЧЕСКОЙ ИНТЕРПРЕТАЦИИ СЕЙСМОРАЗВЕДОЧНЫХ И ЭКСПЕРИМЕНТАЛЬНЫХ МАТЕРИАЛОВ}

4.1. Сеть разрывов Северо-Тамбейской площади, по данным анализа куба сейсмической информации

При отсутствии в пределах Северо-Тамбейского участка плотной сети скважин наиболее информативными для выделения разломных зон являются данные сейсморазведки. В качестве основы для построений использовался куб сейсмической информации, полученный при обработке и интерпретации материалов 3D МОГТ. Для выявления разрывных нарушений сейсмокуб был обработан в специализированном программном комплексе путем расчета структурных атрибутов сейсмической записи «Дисперсия» и «Ант-трекинг», которые наиболее эффективны для решения подобных задач [Pedersen et al., 2002; Silva et al., 2005; Aarre et al., 2012; Basir et al., 2013; Khair et al., 2012].

Выявление разломных зон осуществлялось на срезах кубов перечисленных атрибутов, рассчитанных для глубинных уровней отчетливо проявленных отражающих горизонтов. На каждом уровне выделялись линейно вытянутые участки сгущения неоднородностей, которые могут представлять разломные зоны. Оценивались длина и мощность каждой зоны, а также их отражение в пределах соседних горизонтов. В итоге для СТУ была получена схема осей крупных разломных зон, которые пересекают участок исследования и проявлены в пределах всего осадочного разреза, а также более мелких структур, нарушающих отдельные блоки (рис. 7, в).

Роза-диаграмма свидетельствует, что сеть нарушений СТУ представлена тремя системами (№ 1-3 на рис. 7, б). По распространенности (рис. 7, б) и количеству крупных разрывных структур (рис. 7, в) преобладает $(a)$

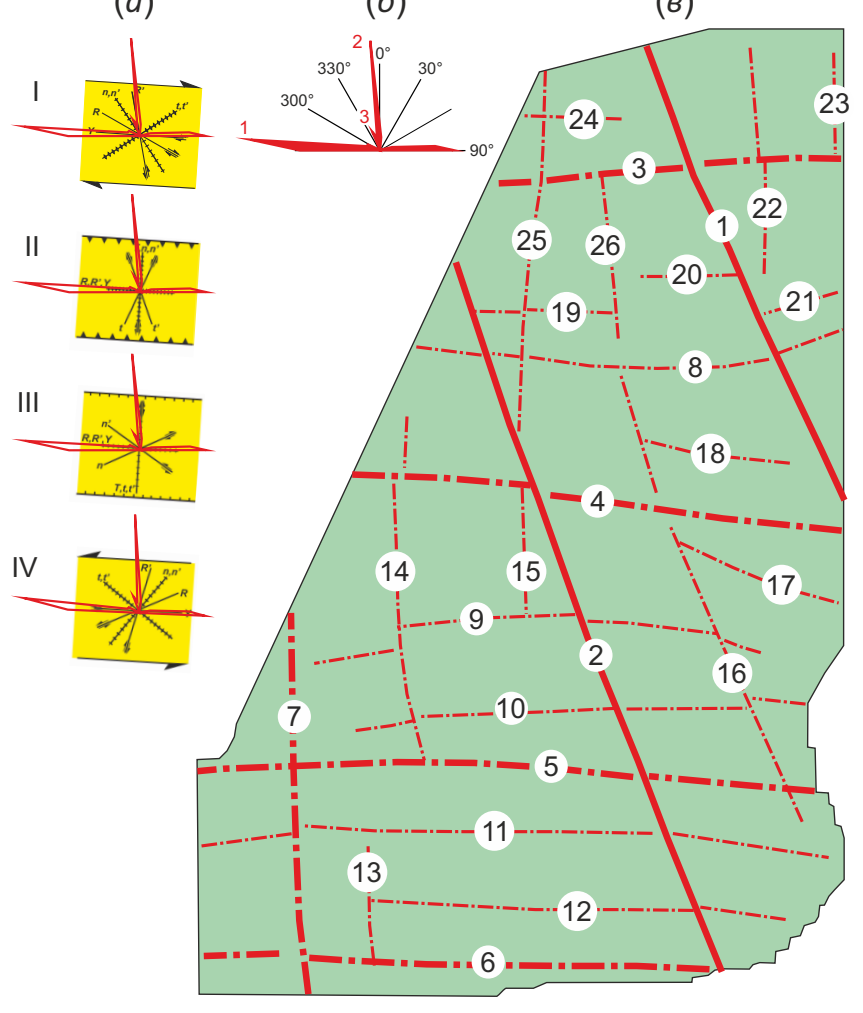

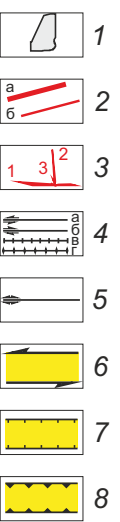

Рис. 7. Результаты парагенетического анализа ( $a$ ) роза-диаграммы разломных зон (б), сеть которых для Северо-Тамбейского участка (в) была выделена при анализе куба сейсмической информации.

1 - контуры площади исследования; 2 - оси крупных (а) и более мелких (б) разломных зон, внутренняя структура которых соответствует ранним (штрихпунктир) и поздним (сплошная линия) стадиям развития; 3 - роза-диаграмма разломных зон (цифры - номера систем); 4-8 - см. обозначения на рис. 4.

Fig. 7. Results of paragenetic analysis (a) of rose diagram of the fault zones (б) whose network ( 8 ) for the North Tambey area was identified through 3-D seismic data analysis.

1 - contours of the study area; 2 - axes of large (a) and smaller (б) fault zones, the inner structure of which corresponds to early (dashdotted line) and late (solid line) development stages; 3 - rose diagram of the fault zones (figures stand for system numbers); $4-8$ - see designations in Fig. 4. 
система 1. Кроме того, ей принадлежат два крупных разлома 2-го ранга (1 и 3 на рис. 5), в блоке между которыми находится Северо-Тамбейская площадь. Как следствие, простирание системы 1 использовалось для ориентации трафаретов левого сдвига, сброса, взброса и правого сдвига в ходе парагенетического анализа, проведенного с целью определения динамических обстановок формирования рассматриваемой разрывной сети.

Как видно из рис. 7 (a-I), она развивалась в обстановке правостороннего сдвига, поскольку все три системы совпадают с положением разрывов 2-го порядка, составляющих данный парагенезис. Это решение локального уровня полностью соответствует обстановке I, реконструированной на региональном уровне для Северного Ямала в целом (см. рис. 5, а). При этом кинематика разломных зон 1 и 3, принимающих в районе СТУ субширотную ориентацию, является правосдвиговой. Согласованность результатов, полученных на локальном уровне при обработке куба сейсмической информации и на региональном уровне при анализе трехмерной модели рельефа, является доказательством достоверности сделанных реконструкций как по динамическим обстановкам, так и по разрывной структуре, поскольку она послужила их основой.

Для исследования особенностей внутреннего строения разломных зон СТУ проводился дополнительный анализ, суть которого заключалась в оценке по серии признаков степени их проявленности на сейсмических разрезах, а также срезах кубов «дисперсия» и «ант-трекинг». Признаками присутствия разломной зоны на сейсмических разрезах (рис. 8, а) являются нарушения сплошности и регулярности отражателей. Выделяются резкие и плавные «деформации» с формированием несогласий, уступов и/или складок, многократные выклинивания и др. Кроме этих признаков, в пределах зоны разлома обычно происходит уменьшение интенсивности цветовой картины, что отражает изменение физико-механических свойств вмещающих пород в результате повышения плотности приразломной трещиноватости и/или заполнения зоны флюидом. На разрезах куба «ант-трекинг» (рис. 8, б) разломные зоны состоят из серии наклонно или вертикально вытянутых линий серого цвета, представляющих следы поверхностей разрывов на плоскости среза. На глубинных срезах куба «дисперсия» (рис. 8, в) разломные зоны представлены вытянутыми аномалиями серокрасного цвета, отражающими несогласия трассирования волновых сигналов исходного куба сейсмических данных.

Перечисленные признаки использовались для трассирования представителей каждой из трех систем дизъюнктивов СТУ (см. рис. 7, б) и установления особенностей их внутреннего строения в неоднородной осадочной толще. В основу анализа была положена экспертная оценка наличия разломной зоны по трехбалльной системе. Баллы 0, 1 и 2 присваивались при отсутствии (0), слабом наличии (1) или присутствии (2) признаков разломной зоны на сейсмическом разрезе, срезе куба «дисперсия» или срезе куба «ант-трекинг». Оценки (a)

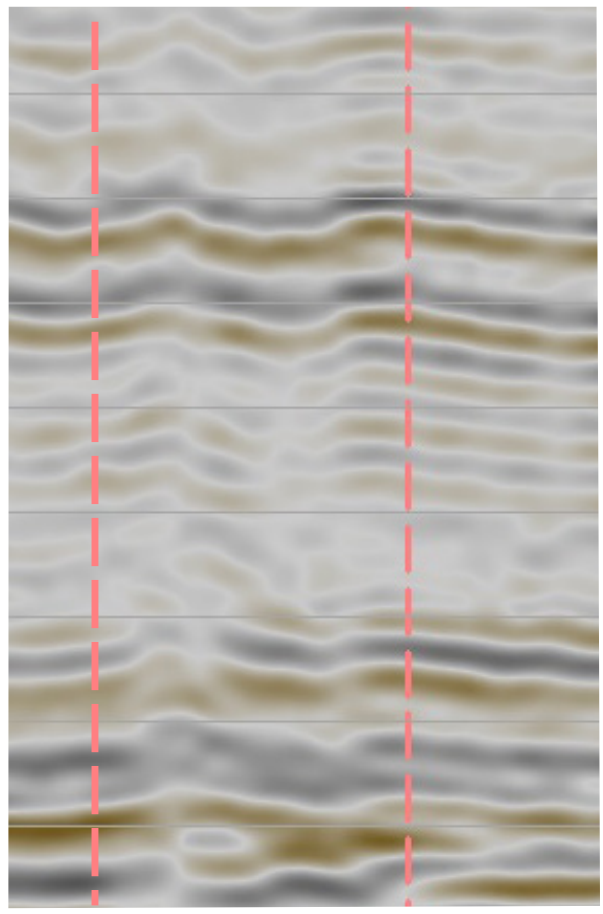

(б)

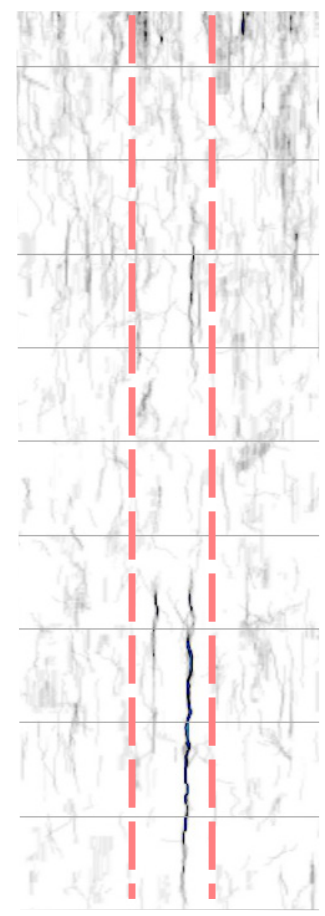

(в)

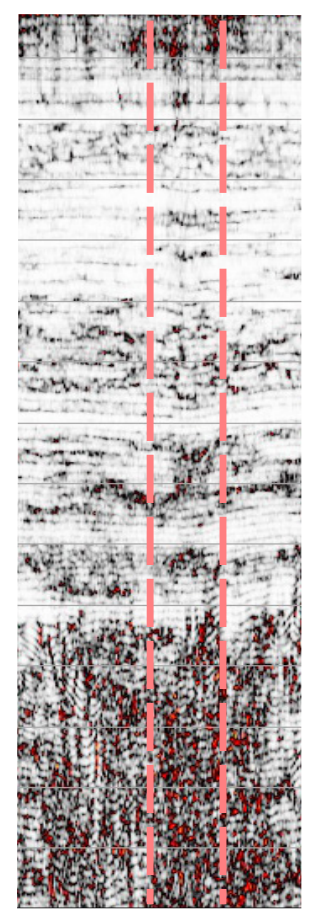

Рис. 8. Проявление разломных зон, структура которых находится на ранних стадиях развития, на сейсмических разрезах (a), а также вертикальных срезах кубов «ант-трекинг» (б) и «дисперсия» (в). Пунктиры - границы зон.

Fig. 8. Manifestation of the fault zones, whose structure is at early development stages, on seismic profiles $(a)$, and vertical sections of "ant-tracking" (б) and "dispersion" ( 8 ) cubes. Dashed lines denote the boundaries of zones. 
проводились для каждых 100 м глубины по поперечным разрезам, пересекающим изучаемый разлом через каждые 1200 м.

Результаты проведенного анализа иллюстрируются здесь на примере двух представителей дизъюнктивов северо-западного простирания (см. зоны 1 и 2 на рис. 7), которые в отличие от других зон во многих частях разреза выражены непрерывными сместителями, т.е. достигли поздних стадий развития внутренней структуры (см. рис. 2, а). На рис. 9 приводятся распределения балльных оценок 0 (красные ячейки), 1 (желтые ячейки) и 2 (зеленые ячейки) в плоскости каждого из разломов, полученных при анализе сейсмических разрезов (рис. 9, а), а также срезов кубов «ант-трекинг» (рис. 9, б) и «дисперсия» (рис. 9, в). Ячейки имеют одинаковый произвольно выбранный размер и используются только для обозначения степени проявленности разломной зоны в последовательно расположенных вдоль нее поперечных срезах.

Рис. 9 свидетельствует об отчетливом проявлении разломов в чехле и фундаменте, но степень их выраженности в отдельных сейсмических имиджах существенно различна. Так, на сейсмических разрезах (рис. 9, а) однозначно выделяется только разлом 1, поскольку большая часть его плоскости залита зеленым и желтым цветом при небольшом количестве красных площадок. В численном отношении это подтверждает величина среднего балла - 1.4. Для разлома 2 данный параметр составляет 1.0, что свидетельствует о его слабом проявлении на сейсмических разрезах. Применение сейсмических атрибутов «ант-трекинг» и «дисперсия», ориентированных на выделение разрывов, существенным образом меняет эти соотношения. Во всех случаях области зеленого и желтого цвета доминируют над участками, окрашенными красным цветом, а средний балл варьируется от 1.4 до 1.6 (рис. 9, б, в).

Рис. 9 позволяет выявить причины неравномерного проявления разломов на СТУ, так как в распределении участков разного цвета проявляются вполне определенные закономерности как по горизонтали, так и по вертикали. Видно, что вдоль плоскости каждого из разломов имеет место чередование участков с отчетливым и менее отчетливым проявлением структуры. В соответствии с принципиальной моделью строения разломной зоны (см. рис. 2, а) можно предполагать, что первые из них представлены участками развития сравнительно протяженных разрывов, а вторые - областями проявления мелких нарушений и трещин.

В отличие от этой продольной неравномерности разная выраженность разломной зоны в вертикальном разрезе обнаруживает отчетливую связь с литологией пород. В первом приближении разрез делится на три части (рис. 9). Разломы явно выражены в фундаменте и в верхней половине осадочного чехла (до глубины $\approx 2700$ м), но существенно слабее проявлены в его нижней части. Кроме того, в чехле на фоне этой неоднородности 1-го порядка имеет место чередование слоев с отчетливо и менее отчетливо выраженной разломной структурой. Как видно из материалов куба «дисперсия» (рис. 9, в), разломы хорошо проявлены в сравнительно хрупких породах (песчаники, алевролиты) и практически не выражены на отметках $\approx 1000,1800$, 2400, 3400 и 4300 м, где разрез представлен преимущественно глинами (см. колонку справа).

Существование для всех изученных разломов подобного характера вертикальной неравномерности объясняется тем, что каждый из них пересекает всю толщу, но проявляется по-разному в слоях, отличающихся степенью пластичности. В пределах интервалов доминирования песчаников разлом представлен сравнительно хорошо локализованной зоной поздней стадии развития (см. рис. 2, а-II), структура которой выявляется с помощью сейсмических атрибутов. В смежных, существенно глинистых слоях зона представлена сгущением мелких разрывов и трещин, что соответствует ранней стадии разрывообразования. Трещины не могут быть достоверно выявлены на данном этапе развития атрибутного анализа. Мелкие разрывы выделяются в глинистых интервалах разреза, но не могут быть отражены на одной схеме с крупными нарушениями. Причиной является необходимость использования для выделения крупных и более мелких разрывов разных значений параметров, используемых при обработке данных атрибутного анализа, что иллюстрируется на примере разлома 2 (рис. 10).

На рис. 10 , а и рис. 10, в, полученных со стандартным набором параметров извлечения разрывов из просчитанного массива, зону разлома 2 составляют протяженные продольные нарушения. Исключение составляет интервал в районе отметки 3400 м, где разрывы подобного ранга не выделяются. Однако в его пределах фиксируются плоскости более мелких нарушений (рис. 10, б, г), если параметры атрибутного анализа заданы более строго в отношении объединения неоднородностей. Следовательно, в пределах большей части разреза (рис. 10, в) структура разломной зоны соответствует поздней стадии развития, для которой характерны сравнительно крупные продольные разрывы (см. рис. 2, а-II). На уровне отметки 3400 м (рис. 10, г) структура отражает раннюю стадию разломообразования, отличающуюся наличием серии небольших разрывных кулис R и R'-типа (см. рис. 2, a-I). Так, на примере разлома 2 проявляется сегментарное строение дизъюнктивов в реологически расслоенном чехле СТУ (рис. 10, д).

Итак, строение разломных зон меняется по простиранию и падению в соответствии с перманентной неоднородностью развития деформаций и различием в реологических свойствах пересекаемых ими слоев. Несмотря на это, использование комплекса сейсмических атрибутов («ант-трекинг», «дисперсия») и принятых способов обработки их кубов оказывается эффективным для выделения разломных зон, а также для установления особенностей их внутреннего строения, влияющих на распределение углеводородов в осадочной толще СТУ. 
(a)

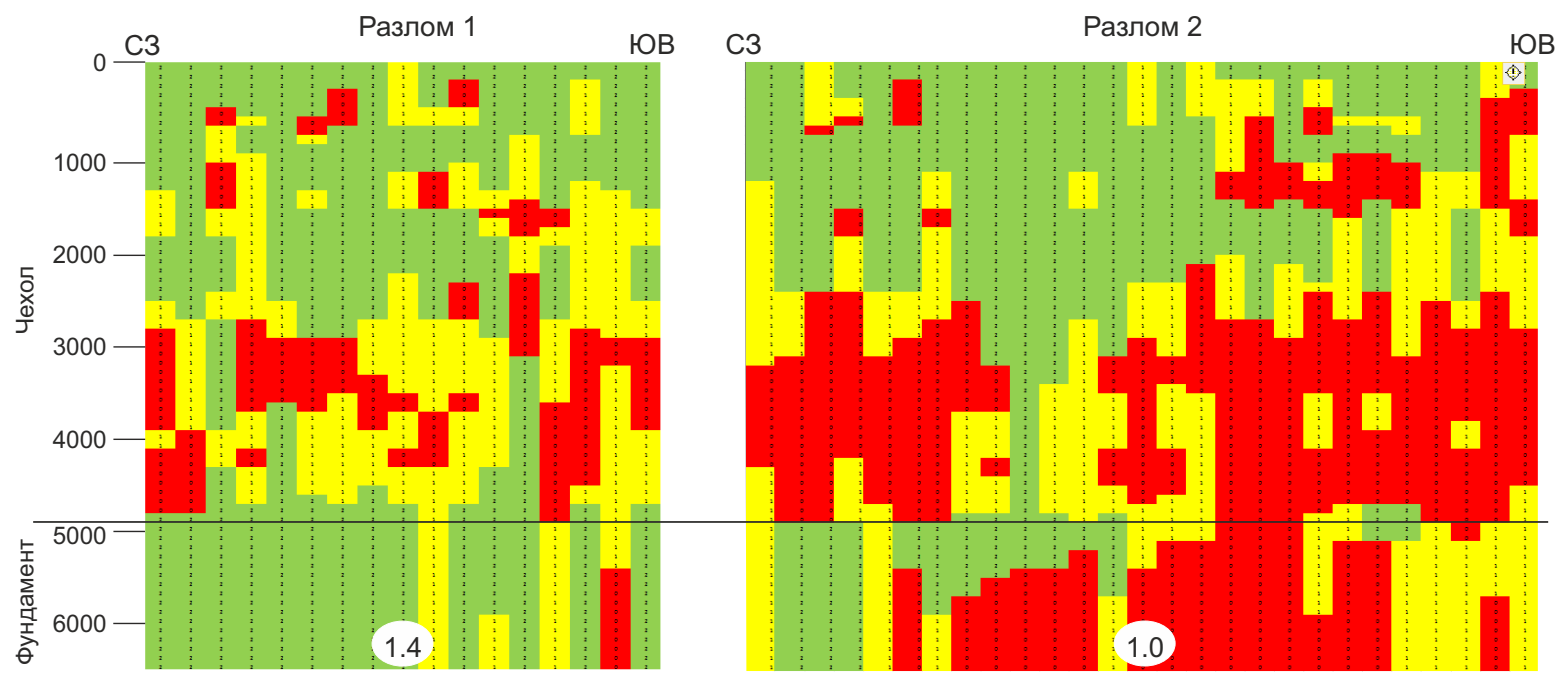

(б)

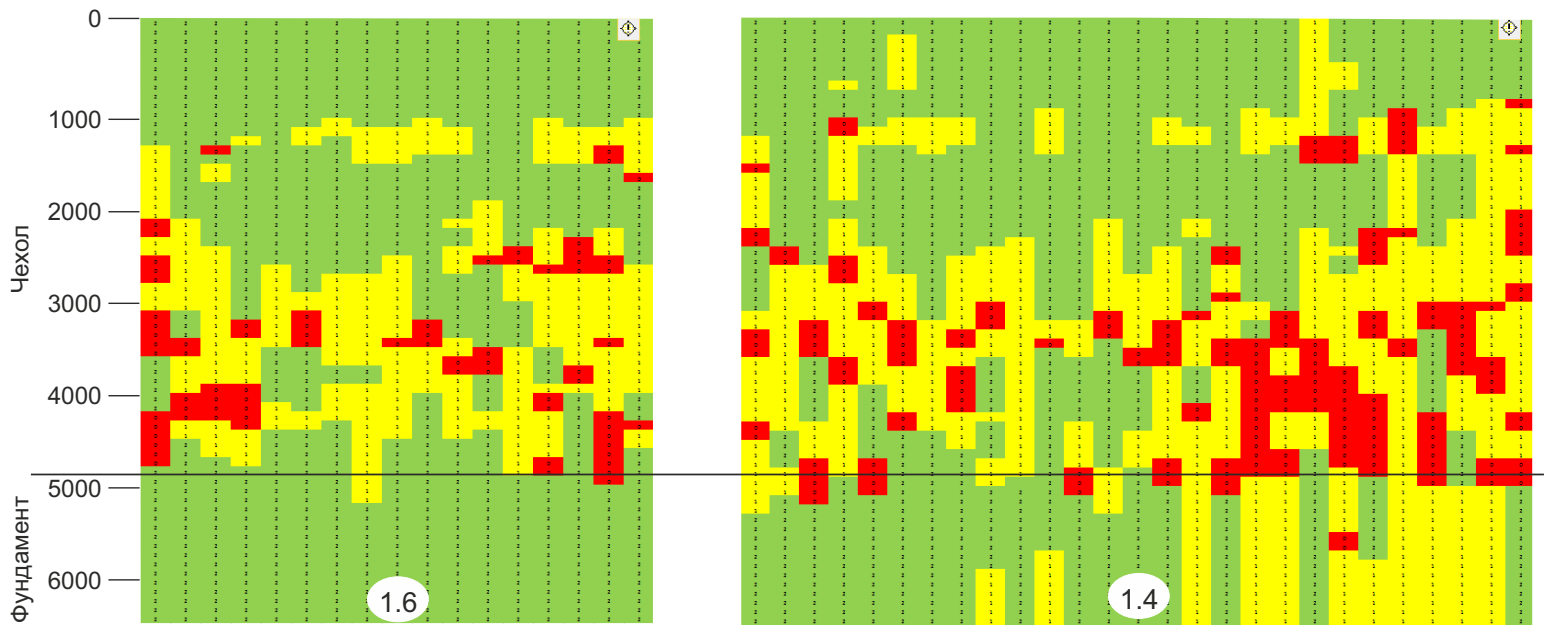

$($ (e)

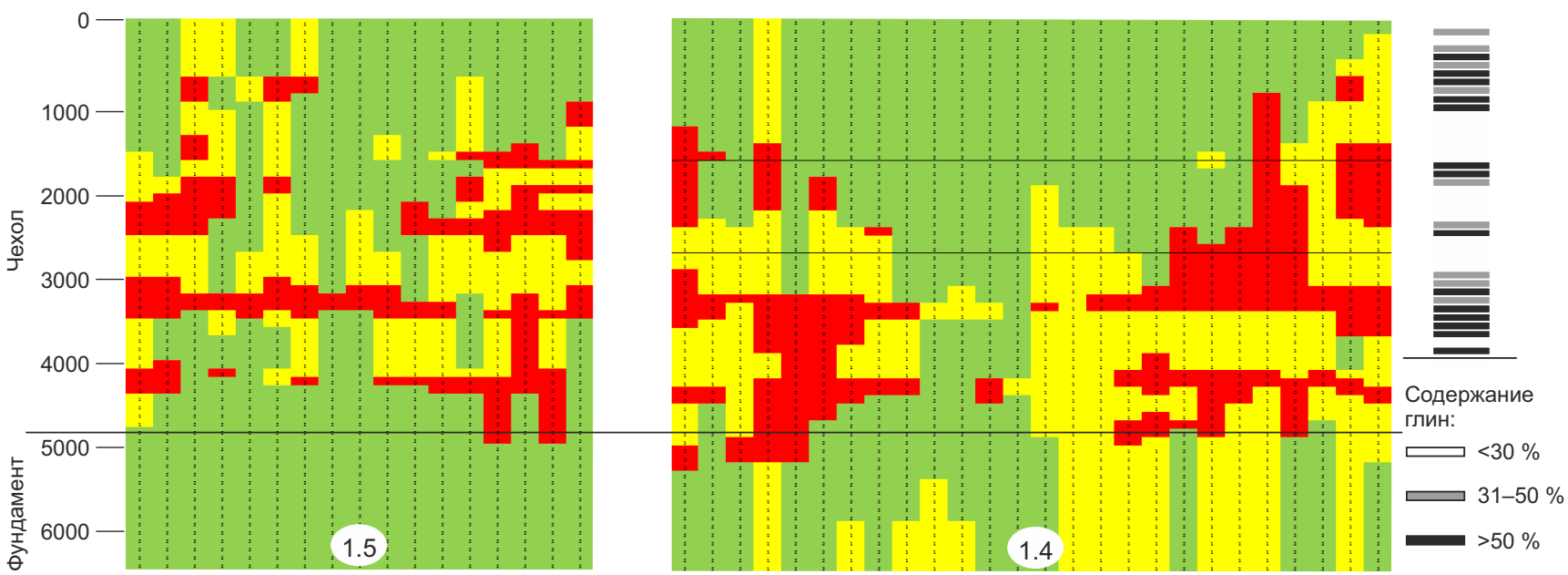

Рис. 9. Распределения балльных оценок 0 (красные ячейки), 1 (желтые ячейки) и 2 (зеленые ячейки) в плоскости разломов 1 и 2, полученных до глубины 6.5 км при анализе сейсмических разрезов (a), срезов куба «ант-трекинг» (б) и срезов куба «дисперсия» ( 8 ). Черные точки маркируют положение ячеек. Средний балл показан в нижней части каждого распределения. Сплошная линия отделяет чехол от фундамента. Справа от фрагмента (в) отмечена степень содержания глин в осадочном разрезе (до глубины $\approx 4000$ м).

Fig. 9. Distribution of scores 0 (red cells), 1 (yellow cells) and 2 (green cells) in fault planes 1 and 2 , obtained to a depth of $6.5 \mathrm{~km}$ through analysis of seismic profiles (а), sections of "ant-tracking" (б) and "dispersion" (в) cubes. Black dots mark the position of cells. The average score is shown in the lower part of each distribution. Solid line separates the cover from the basement. On the right fragment $(B)$ is the degree of clay content in the sedimentary cross-section (to a depth of $\approx 4000 \mathrm{~m}$ ). 
(a)

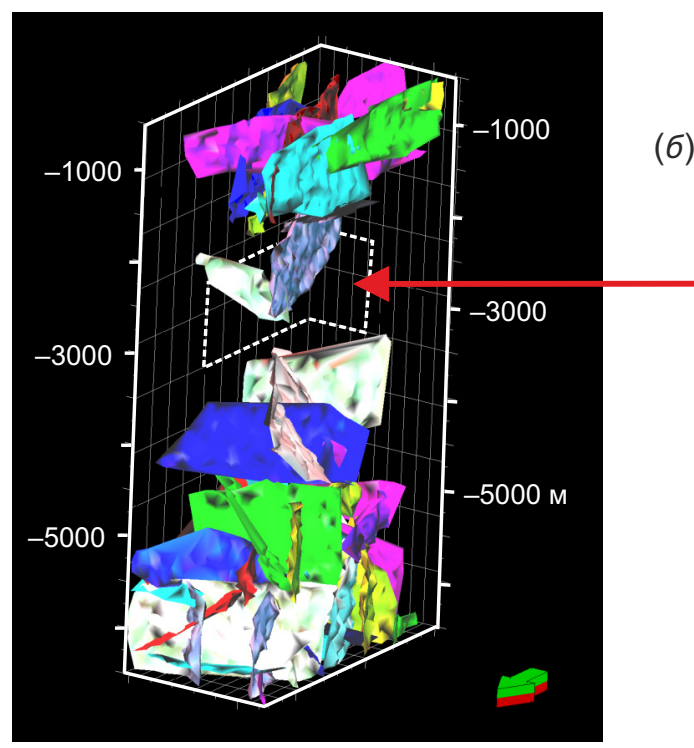

(в)

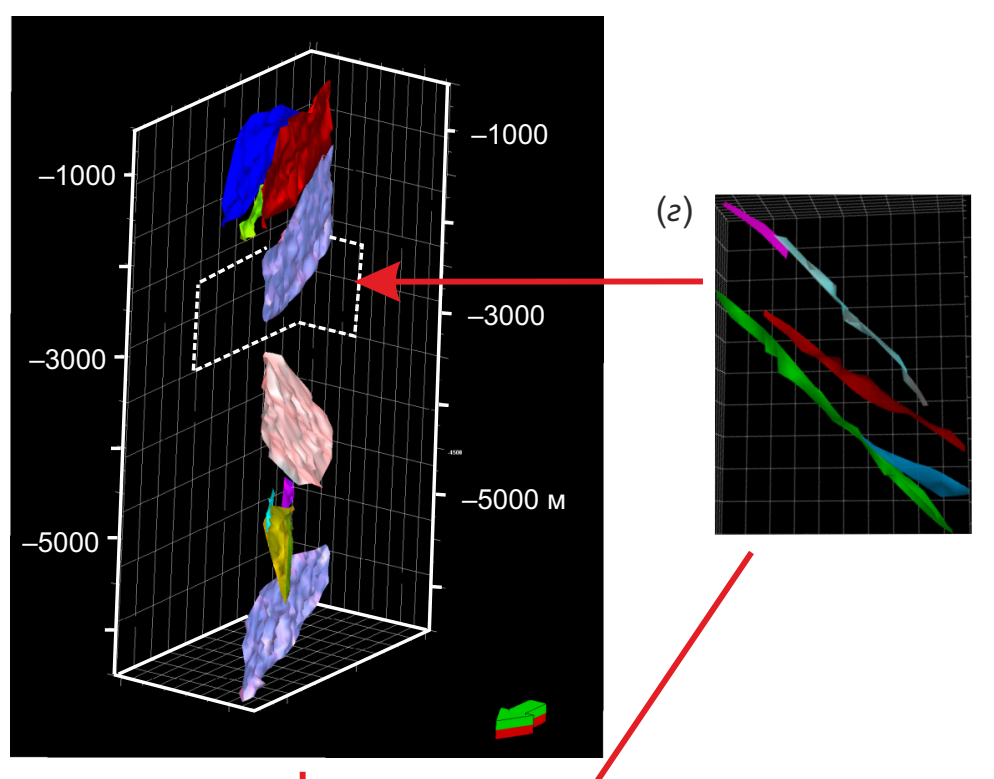

(d)
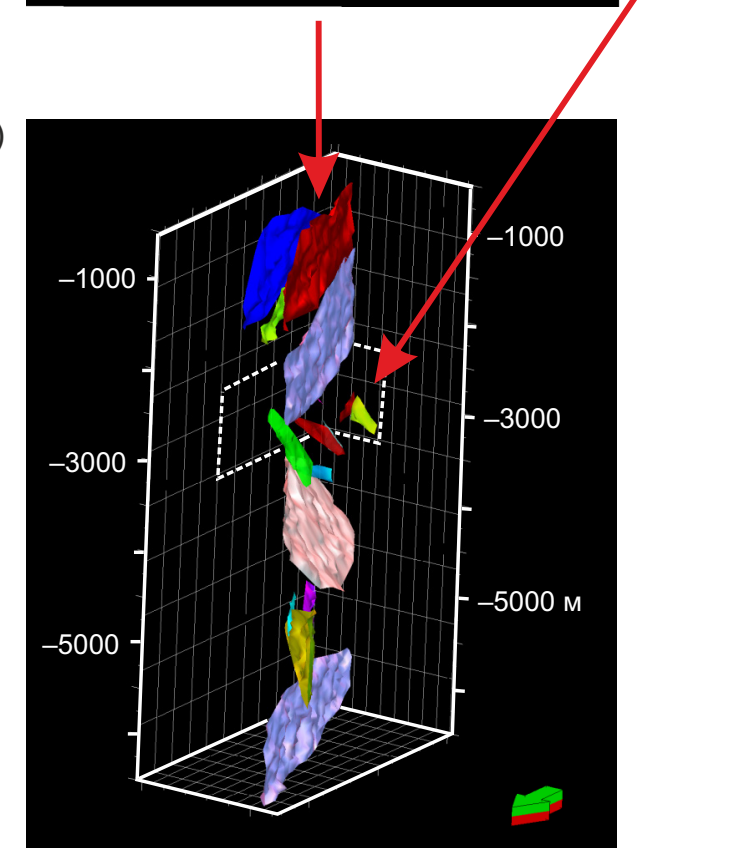

(б)

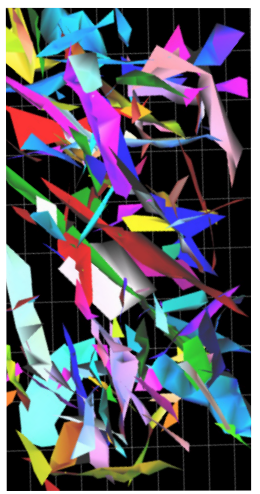

Рис. 10. Внутренняя структура разломной зоны 2, выявленная посредством использования различных параметров извлечения разрывных поверхностей (показаны разным цветом) из интегрального куба сейсмической информации («дисперсия»+«ант-трекинг»).

(a) - поверхности разрывов, окружающих разломную зону в интервале глубин $-500 \ldots-6500$ м, которые были выделены из сейсмокуба при стандартном наборе параметров; (б) - поверхности разрывов, окружающих разломную зону в интервале глубин $-2500 . . .-3500$ м (оконтурен белым пунктиром), которые были выделены из сейсмокуба при наборе параметров, ограничивающем объединение мелких нарушений; $(8)$ - поверхности разрывов, составляющих внутреннюю структуру разломной зоны в интервале глубин $-500 \ldots$ -6500 м, которые были выбраны из всей совокупности фрагмента $(a)$, как наиболее крупные и субпараллельные простиранию изучаемой зоны; (2) - поверхности разрывов, составляющих внутреннюю структуру разломной зоны в интервале глубин $-2500 \ldots-3500$ м, которые были выбраны из всей совокупности фрагмента (б), как наиболее крупные и субпараллельные простиранию изучаемой зоны; ( $\partial)$ - поверхности разрывов, составляющих внутреннюю структуру разломной зоны в интервале глубин $-500 \ldots-6500$ м в соответствии с фрагментами (в) и (2).

Fig. 10. Inner structure of fault zone 2 , identified with extraction of different fault-surface parameters (shown in various colors) from the integrated 3D seismic data ("dispersion"+"ant-tracking").

(a) - surfaces of the faults surrounding the fault zone in the depth interval $500 \ldots$ to $6500 \mathrm{~m}$, identified from 3D seismic data at a standard parameter set; (6) surfaces of the faults surrounding the fault zone in the depth interval $2500 \ldots$ to $3500 \mathrm{~m}$ (contoured by white dashed lines) which were identified from 3D seismic data at a parameter set limiting the integration of small faults; $(\theta)$ - fault surfaces comprising the inner structure of the fault zone in the depth interval $500 \ldots$ to $6500 \mathrm{~m}$, which were selected from fragment $(a)$ as the largest and subparallel to the strike of the study area; (2) - fault surfaces comprising the inner structure of the fault zone in the depth interval $2500 \ldots$ to $3500 \mathrm{~m}$, which were selected from fragment (б) as the largest and subparallel to the strike of the study area; $(\partial)$ - surfaces of the faults comprising the inner structure of the fault zone in the depth interval $500 \ldots$ to $6500 \mathrm{~m}$ in compliance with fragments ( 8 ) and (2). 


\section{2. Дополнительные признаки выделения и особенности формирования разломных зон в осадочном чехле Северо-Тамбейского участка}

В данном разделе на основе имеющихся для СТУ геофизических данных и результатов тектонофизического моделирования рассмотрена серия дополнительных признаков наличия разломных зон, а также причины и особенности их сегментного строения, отражающегося в материалах сейсморазведки чередованием явно выраженных «разломных имиджей» и их отсутствием в смежных горизонтах (см. рис. 9).

Результаты атрибутного анализа куба сейсмической информации на предмет выделения путей миграции углеводородов. Атрибутный анализ сейсмокуба позволяет, кроме собственно разрывов, выделить структуры, которые косвенно подтверждают существование проницаемых разломных зон в осадочной толще СТУ. Как видно на срезах кубов двух сейсмических атрибутов (рис. 11), они (площадка 1) в отличие от разрывов (площадка 2) имеют изометричную форму. Анализ серии погоризонтных срезов позволил на некоторых участках проследить эти структуры до глубины 2 км (рис. 12), что свидетельствует об их трубообразной форме.
В глубоких частях осадочной толщи под этими структурами зачастую располагаются обширные области темного цвета, которые имеют на вертикальных и горизонтальных срезах неправильную форму (рис. 12, а, г) и могут рассматриваться в качестве УВ-насыщенных объектов. Выходы описываемых трубообразных структур на поверхность совпадают с крупными озерами или серией близкорасположенных мелких водоемов (рис. 13, а).

Перечисленные признаки свидетельствуют об отражении в сейсмических имиджах так называемых газовых труб, которые представляют пути миграции газа от залежей УВ к поверхности [Girshgorn, Kabalyk, 1990; Nezhdanov et al., 2012]. Генетическая связь крупных озер и других приповерхностных структур с дегазацией объясняется деградацией многолетнемерзлых пород и образованием термокарста [Bogoyavlensky et al., 2019]. Карстовые полости постепенно заполняются грунтовыми водами и атмосферными осадками, что способствует формированию естественных водоемов.

Поскольку наиболее проницаемыми участками чехла являются разломы, приуроченность к зонам их влияния газовых труб и крупных озер отчетливо отражается в материалах по СТУ. Так, большинство максимумов
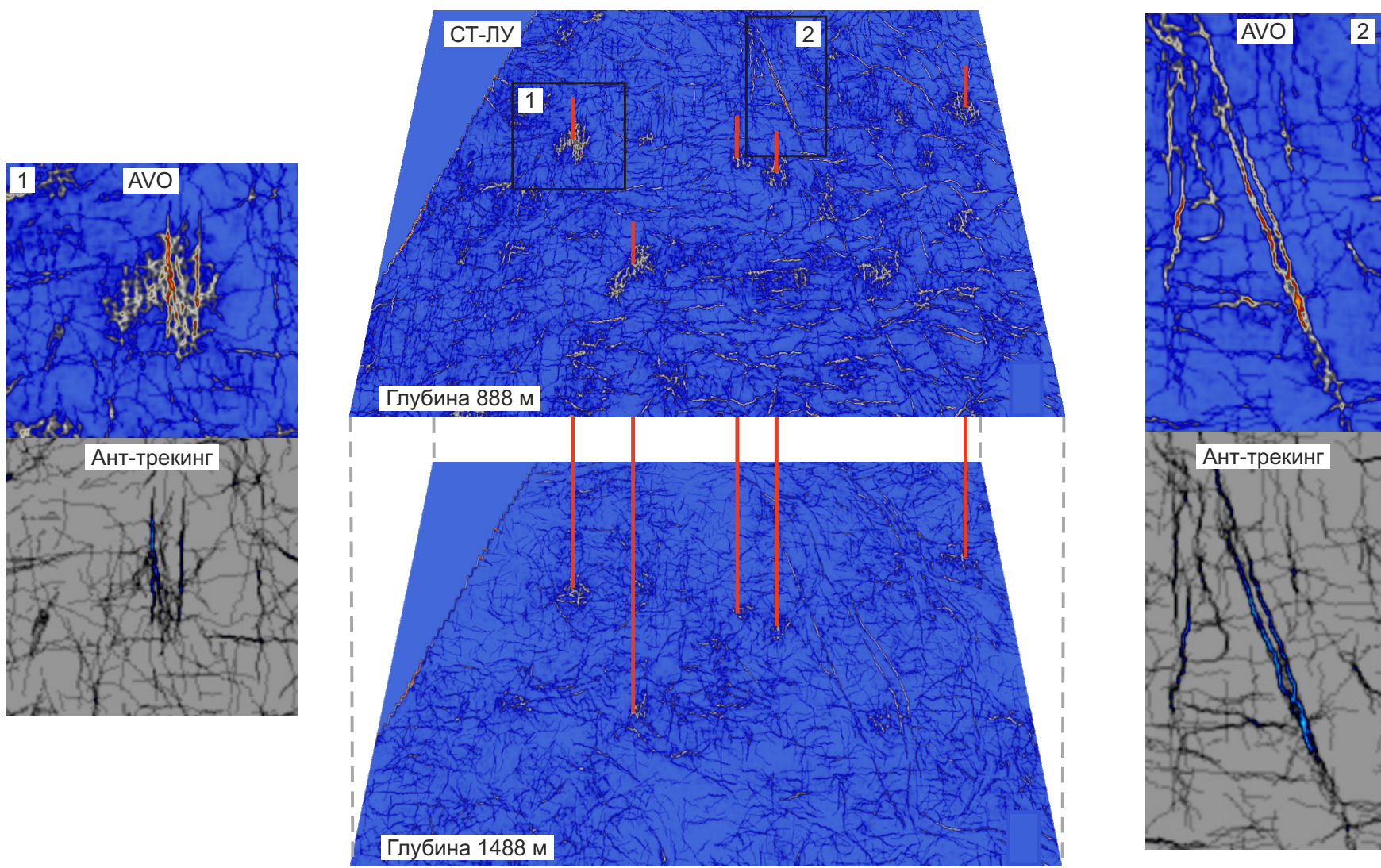

Рис. 11. Проявление различных структур на горизонтальных срезах кубов AVO-атрибутов и «ант-трекинга», представленных для двух глубинных уровней СТУ: 888 и 1488 м. Красным выделены осевые линии трубообразных тел, положение которых косвенно подтверждается наличием озер на дневной поверхности.

Fig. 11. Manifestation of different structures on horizontal sections of AVO attribute and "ant-tracking" cubes represented for two NTA depth levels: 888 and $1488 \mathrm{~m}$. Red colors show the axial lines of pipe-shaped bodies whose location is indirectly confirmed by the presence of lakes on the surface. 


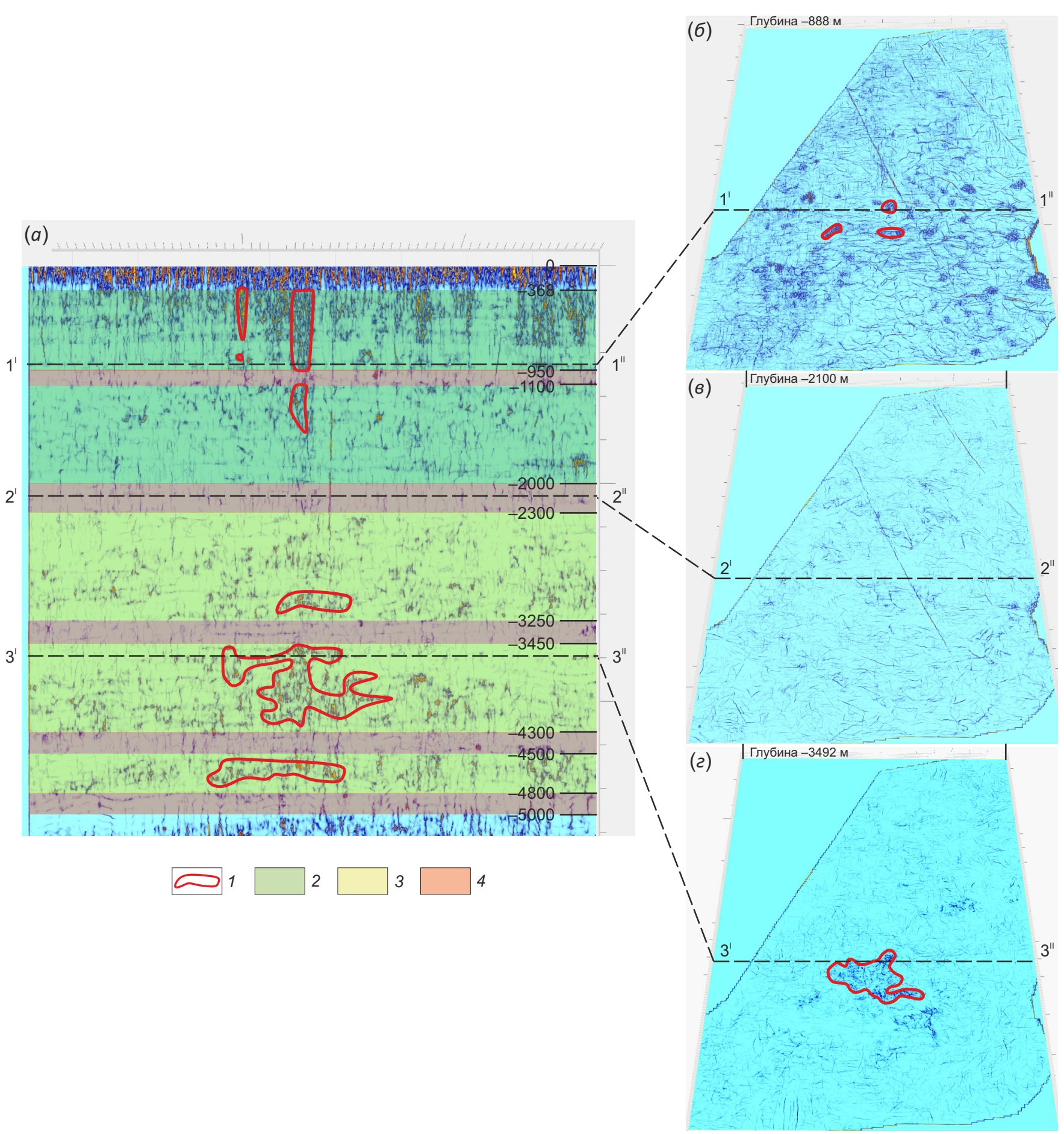

Рис. 12. Закономерности строения газовых труб в реологически неоднородном разрезе осадочной толщи на СевероТамбейском участке.

$(a-2)$ - вертикальный $(a)$ и горизонтальные (б-2) срезы куба атрибутов. 1 - аномалии, на примере которых рассматриваются общие закономерности строения газовых труб в пространстве; 2 - пласты, в которых отчетливо видны аномалии в форме трубообразных структур; 3 - пласты, в которых аномалии под влиянием высокого литостатического давления представляют обширные области размещения газа в диффузном состоянии; 4 - пласты существенно глинистого состава, в которых выделение аномалий затруднено вследствие слабой проявленности разрывной структуры.

Fig. 12. Regularities in the structure of gas pipes in a rheologically inhomogeneous sedimentary cross-in the northern Tabmey area. $(a-2)$ - vertical $(a)$ and horizontal $(6-2)$ sections of the attribute cube. 1 - anomalies to show general trends in the structure of gas pipes in space; 2 - seams which have clearly defined anomalies in the form of pipe-shaped structures; 3 - seams wherein the high-lithostatic-pressure-affected anomalies represent vast diffused gas areas; 4 - seams composed primarily of clay, which makes it difficult to identify anomalies due to poorly defined faulting structure. 

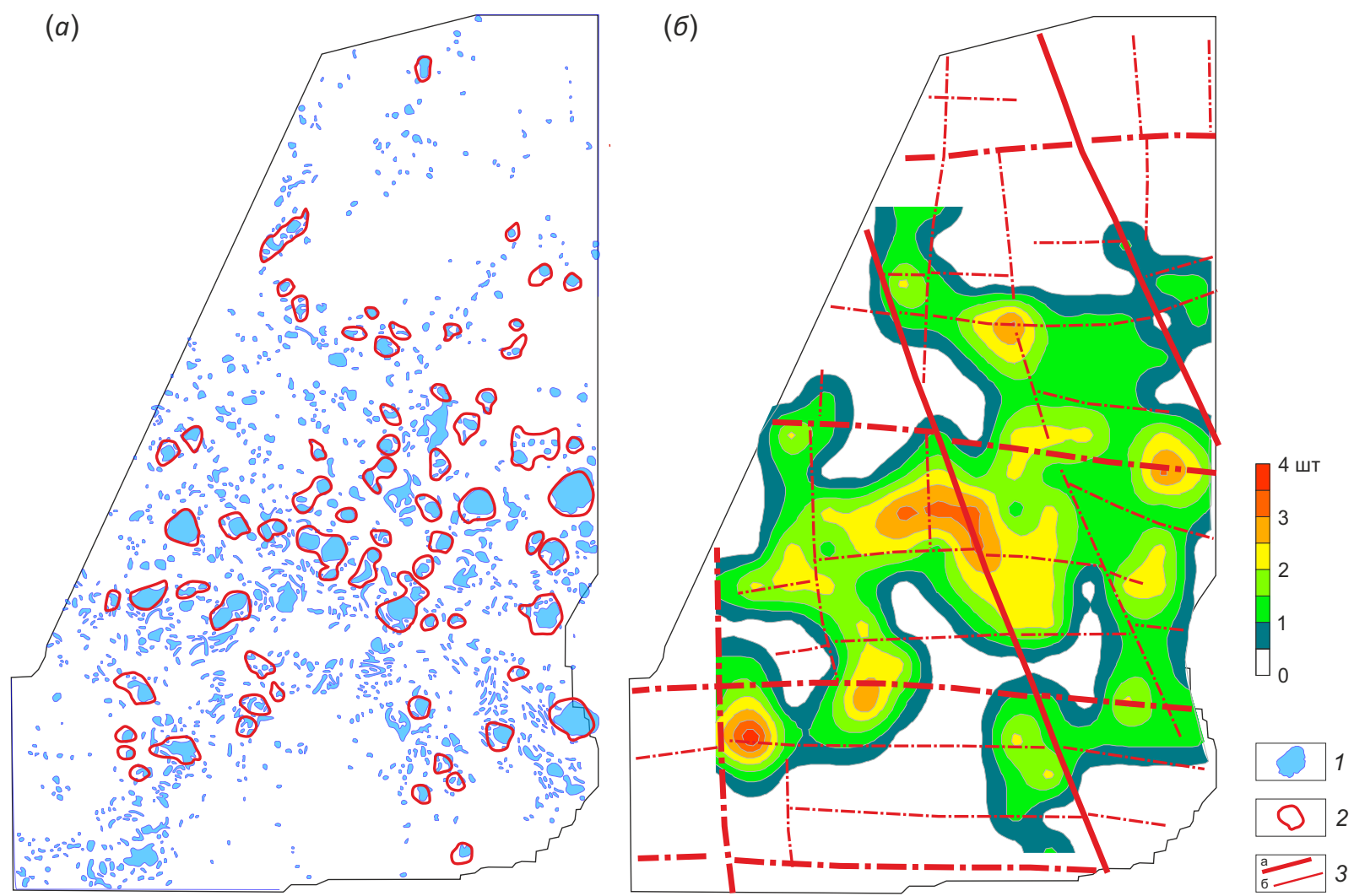

Рис. 13. Закономерности распределения газовых труб в пределах Северо-Тамбейского участка.

(a) - озера с проекциями газовых труб на дневной поверхности; (б) - карта плотности газовых труб в изолиниях. 1 - озера; 2 - проекции газовых труб на поверхности; 3 - оси крупных (а) и более мелких (б) разломных зон, внутренняя структура которых соответствует ранним (штрихпунктир) и поздним (сплошная линия) стадиям развития.

Fig. 13. Regularities of gas-pipe distribution of within the northern Tambey area.

(a) - lakes with gas-pipe projections on the surface; (6) - map of gas-pipe density in isolines. 1 - lakes; 2 - gas-pipe projections on the surface; 3 - axes of large (a) and smaller (б) fault zones whose inner structure corresponds to early (dashed-dotted line) and late (solid line) development stages.

плотности газовых труб в верхней части чехла тяготеют к разломам и узлам их пересечения (рис. 13, б). То же характерно и для более глубоких участков разреза (см. рис. 11) за исключением отдельных слоев, где по сейсмическим имиджам их присутствие практически не устанавливается (см. рис. 12, а). Как видно из рис. 9, в, это те глинистые слои, где мелкие разрывы, представляющие структуру зоны, могут быть выявлены только при специальных параметрах атрибутного анализа (см. рис. 10, г, д).

Присутствие газовых труб выше и ниже интервалов распространения глин является косвенным свидетельством существования на изучаемом участке разреза единой разломной зоны, имеющей сегментное строение. Газы, мигрирующие от залежи к поверхности, проходят через слои сравнительно пластичных пород по системе трещин и мелких разрывов, представляющих в их пределах структуру разломной зоны, которая на смежных интервалах ввиду появления более крупных нарушений отчетливо отражается в сейсмических имиджах.

Данные тектонофизического моделирования. Сегментное строение разломных зон в реологически расслоенной толще объясняют результаты моделирования на упругопластичных материалах. Методика проведения экспериментов и критерии подобия моделей природному аналогу подробно представлены в специальных публикациях [Sherman et al., 1983; Seminsky, 2003; Bokun, 2009]. В данном случае воспроизводилось формирование субвертикальной разломной зоны в чехле над разломом в фундаменте, роль которого выполняли жесткие штампы экспериментальной установки, один из которых опускался вниз с постоянной скоростью. Деформировались модели из влажной глины и влажного песка, которые являются аналогами более (глина) и менее (песчаник) пластичных пород платформенного чехла.

После начала движения штампа разрывы в сравнительно пластичной глинистой модели (рис. 14, а, в) начинают прорастать от ее основания к поверхности в пределах широкой зоны, причем для формирования магистрального шва требуются существенные амплитуды вертикального перемещения. Более хрупкая модель из песка (рис. 14, б, г), напротив, быстро разрушается одним разрывом при небольшой амплитуде смещения штампа. 
(a)

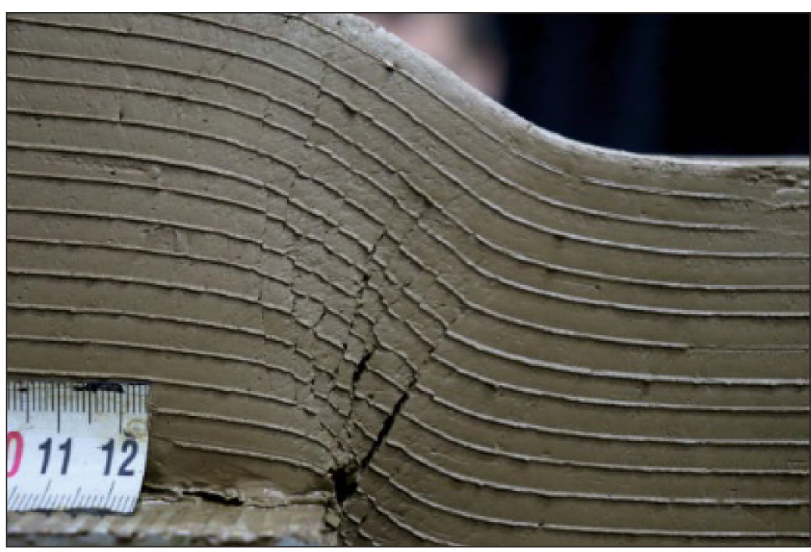

(б)

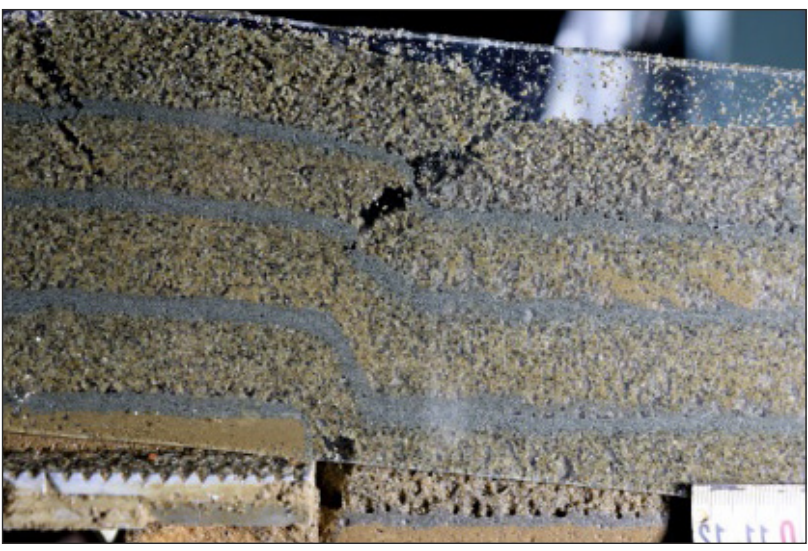

(B)

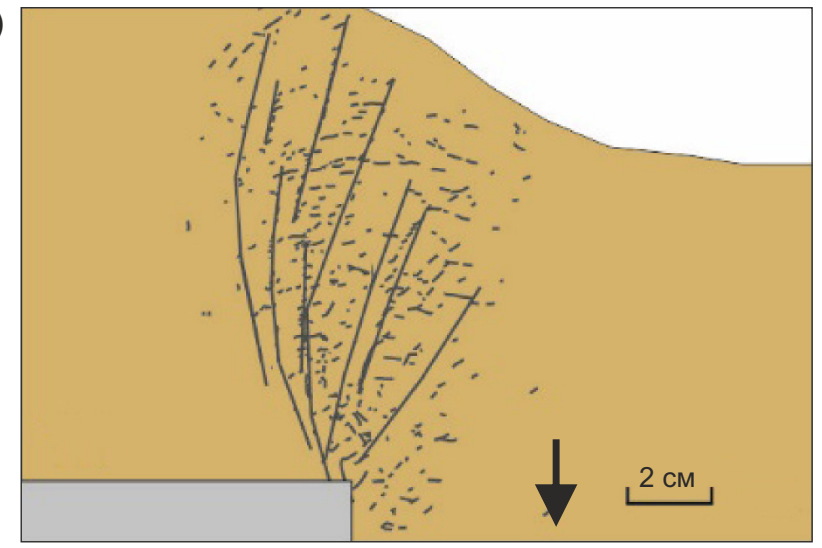

(2)

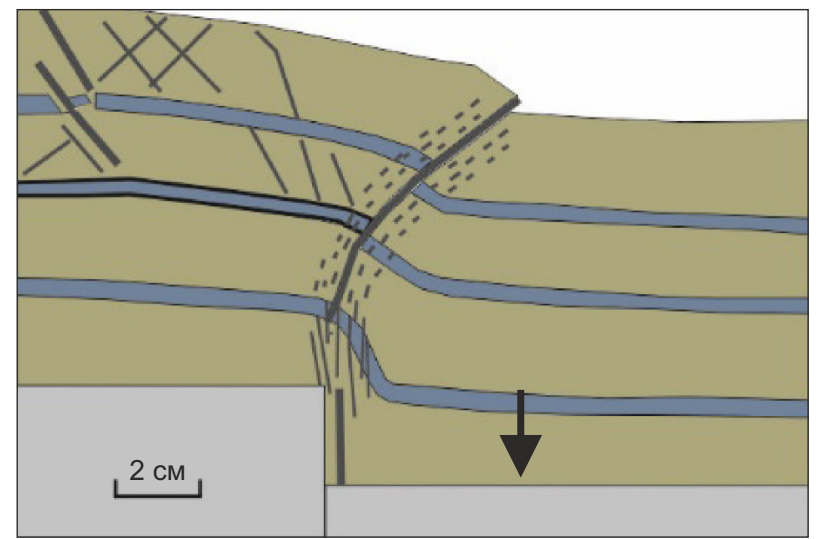

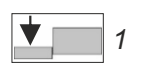

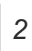

3 4

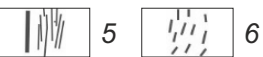

Рис. 14. Зоны разрывов, образовавшиеся за одно и то же время в чехле над активным разломом фундамента в моделях из глины $(a)$ и влажного песка (б). Схемы разрывов в моделях из глины (в) и влажного песка (2).

1 - штампы экспериментальной установки (стрелка - направление движения активного штампа); 2-3 - модели из глины (2) и песка (3); 4 - маркеры; 5 - разрывы; 6 - область разрыхления модельного материала.

Fig. 14. Clay (a) and wet sand (б) models of fault zones formed at the same time in the cover above active basement fault. Clay ( 8 ) and wet sand (2) models of faulting schemes.

1 - stamps of an experimental unit (arrow shows the direction of the motion of an active stamp); $2-3$ - clay (2) and sand (3) models; 4 - marker; 5 - faults; 6 - an area of model-comprising material softening.

Следовательно, в относительно хрупкой среде (песчаники) при прочих равных условиях структура разломной зоны доходит до стадии полного разрушения, т.е. появления магистрального сместителя (разрыв 1-го порядка) или его крупных сегментов, которые отчетливо проявлены линейными формами в сейсмических материалах (см. рис. 11, 12). В более пластичных осадках (глины) структура зоны соответствует ранним стадиям разломообразования, представленным сгущением сравнительно мелких разрывов и трещин. Как показывает опыт анализа куба сейсмической информации, при наличии разрывов 2-го порядка зона может быть протрассирована через пластичный слой (см. рис. 10). Однако, если она представлена лишь сгущением трещин, то разрешающей способности сейсморазведки недостаточно для ее выделения.

Таким образом, сегментарный характер проявления разломных зон в сейсмических имиджах является закономерным для платформенных регионов и объясняется, во-первых, их развитием в породах с разной степенью пластичности и, во-вторых, чувствительностью сейсморазведки, недостаточной для выделения разрывных структур ранга трещин.

\section{5. СПЕЦИФИКА РАЗЛОМНОЙ СТРУКТУРЫ СЕВЕРНОГО ЯМАЛА С АКЦЕНТОМ НА СТРОЕНИИ И НАПРЯЖЕННОМ СОСТОЯНИИ ПЛАТФОРМЕННОГО ЧЕХЛА В ПРЕДЕЛАХ ЦЕНТРАЛЬНОЙ ЧАСТИ ТАМБЕЙСКОГО МЕСТОРОЖДЕНИЯ УГЛЕВОДОРОДОВ}

В соответствии со структурой статьи результаты проведенного исследования обобщены в данном разделе как следствие анализа общих представлений современной геодинамики и тектонофизики о происхождении и строении разрывных нарушений (раздел 2), а также как результат комплексного исследования структуры осадочного чехла на региональном (Северный 
Ямал) (раздел 3) и локальном (Северо-Тамбейский участок) (раздел 4) уровнях.

1. Согласно общим представлениям геодинамики, внутренние части платформ (и тем более регион Северного Ямала) находятся под влиянием тектонических напряжений, действующих на границах литосферных плит. Даже при минимальном воздействии образование первичной трещиноватости в ходе диагенеза платформенных осадков происходит под влиянием этой «тектонической рамы», что приводит к созданию не хаотической, а системной разрывной сети. Как следствие, для п-ва Ямал каждый из крупных этапов развития ближайших межплитных границ должен в большей или меньшей степени отражаться в разрывной структуре его осадочного чехла.

Кроме системной трещиноватости, неизбежным элементом такой структуры являются зоны повышенной плотности трещин и мелких разрывов. Согласно представлениям тектонофизики (см. рис. 2, а), они соответствуют ранним стадиям развития разломов (стадия I и II), которые, в отличие от заключительной стадии III, не содержат в своем строении единого магистрального сместителя (см. рис. 3). Эти общие представления позволяют априори предполагать, что в связи с воздействием тектонических сил осадочный чехол Ямала в целом и СТУ в частности характеризуются структурной неоднородностью. По меньшей мере, он должен быть разделен зонами повышенной трещиноватости на относительно слабонарушенные блоки как на региональном, так и на локальном уровне.

2. Исследования в региональном масштабе позволили установить, что верхняя часть осадочного чехла Северного Ямала имеет зонно-блоковую структуру, т.е. представляет иерархию блоков, контактирующих по достаточно широким разломным зонам (см. рис. 4, а, б). Согласно тектонофизическим реконструкциям (см. рис. 4, в), она сформировалась как минимум в трех полях напряжений регионального уровня (см. рис. 4, г, рис. 5), связанных с основными этапами тектонического развития смежных с платформой межплитных границ. Это поле сдвига с северо-западной ориентацией оси сжатия и северо-восточной - оси растяжения (I), поле сдвига с субмеридиональной ориентировкой оси сжатия и субширотной - оси растяжения (II) и поле растяжения в субмеридиональном направлении (III).

Тектонофизическое моделирование на оптически активном материале (см. рис. 6) позволило установить характер распределения напряжений в зонно-блоковой структуре Северного Ямала, соответствующий каждой из трех динамических обстановок (I-III). Показано, что расположение Тамбейского месторождения углеводородов контролируется областями пониженных напряжений, которые формируются в блоках при сдвиге (см. рис. 6, г, д), причем для поля I - с достаточно отчетливым совпадением контуров (см. рис. 6, в, г). Более того, в северной части Северо-Тамбейской площади и на Тасийском участке залежи находятся в узле пересечения крупных разломных зон, локализуясь в противоположных квадрантах, где в динамической обстановке I доминируют условия растяжения, способствующие концентрации углеводородов (см. рис. 5, а).

Таким образом, исследования на региональном уровне дали возможность установить вид разломной структуры Северного Ямала и динамические обстановки ее формирования, предполагаемые априори в соответствии с общими представлениями тектонофизики о характере нарушенности платформенного чехла. Достоверность полученных реконструкций косвенно подтверждается закономерным расположением залежей Тамбейского месторождения на участках, благоприятных для концентрации углеводородов. Это области пониженных напряжений, которые образуются вследствие перемещений по сети выявленных разломных зон в региональном поле сдвига.

3. Локальный уровень исследований разломной структуры, реализованный в пределах Северо-Тамбейского участка, базировался главным образом на результатах анализа материалов 3D сейсморазведки и проведении тектонофизического моделирования на упругопластичном материале.

Атрибутный анализ куба сейсмической информации послужил основой для картирования сети разрывных нарушений в осадочной толще СТУ (см. рис. 7). Однако детальное исследование ряда представителей выделенных структур на погоризонтных планах и вертикальных разрезах всей толщи чехла свидетельствует об их сегментарном проявлении в сейсмических имиджах (см. рис. 8, 9, 10). Это дает повод для заключения об отсутствии разрыва и бескорневом разломообразовании. Вместе с тем с позиций тектонофизики это единые структуры - разломные зоны, а сегментный характер их проявления в сейсмических имиджах для большинства случаев является следствием недостаточной «чувствительности» сейсморазведки для определения специфики разрывообразования в реологически расслоенной осадочной толще.

Так, на тектонически слабоактивных платформенных территориях разломы в большинстве случаев представлены ранней стадией развития внутренней структуры (стадия I на рис. 2, а). Это зоны повышенной плотности трещин и небольших разрывов, смещения по которым не могут определяться на сейсмических имиджах, а в случае представленности зон одной трещиноватостью - даже при атрибутном анализе куба сейсмической информации. Некоторые разрывные нарушения, выделенные для СТУ, по степени зрелости внутренней структуры относятся к более продвинутой стадии развития (стадии II на рис. 2, а). Однако они, как и любые другие разломы, характеризуются неоднородностью строения не только вкрест, но и вдоль простирания (см. рис. 2, а, в). В разломной зоне чередуются узкие участки проявления сравнительно крупных разрывов и широкие области распространения трещин и мелких разрывов. В реологически неоднородной осадочной толще их положение определяется степенью компетентности слоев по отношению к деформации. 
Установлено, что в сейсмических имиджах осадочной толщи СТУ разломы отчетливо проявлены в сравнительно хрупких комплексах с доминированием песчаников и почти не выделяются в маломощных слоях относительно пластичных глин (см. рис. 9, в, рис. 12, а). Результаты лабораторных экспериментов по воспроизведению процесса формирования разломной зоны в упругопластичных моделях подтверждают эту закономерность. За один и тот же временной интервал при прочих равных условиях в песчаном слое формируется единый сместитель, а в глинистом - широкая зона сравнительно мелких разрывов (рис. 14).

Это объясняет сегментный характер проявления в сейсмических имиджах разломных зон, которые пересекают породы СТУ, отличающиеся по структурномеханическим свойствам. Косвенными признаками их присутствия является наличие в разломной зоне каналов миграции газа от залежей к поверхности (см. рис. 11, 12), где они способствуют образованию крупных озер (см. рис. 13). Существование трубообразных каналов под и над сравнительно пластичным слоем (см. рис. 12) свидетельствует о миграции через него углеводородов по сети трещин, которые не отражаются в сейсмических имиджах вследствие малой протяженности.

Следует отметить, что сети разломных зон Северного Ямала (региональный уровень) и Северо-Тамбейской площади (локальный уровень) характеризуются иерархической соподчиненностью и по реконструкциям поля напряжений отражают деструкцию осадочного чехла в одних и тех же условиях (см. рис. $5,6,7$ ). Согласованность результатов, полученных на региональном уровне при анализе трехмерной модели рельефа и на локальном уровне при обработке куба сейсмической информации, является доказательством достоверности сделанных реконструкций как по динамическим обстановкам, так и по разрывной структуре, которая послужила основой для восстановления полей напряжений.

\section{6. ЗАКЛЮЧЕНИЕ}

Применение тектонофизического подхода к анализу большого объема геолого-геофизической информации по крупнейшему на п-ве Ямал Тамбейскому месторождению углеводородного сырья позволило установить специфику формирования и закономерности проявления разломов в платформенном чехле.

Структура осадочного чехла на платформах является зонно-блоковой, т.е. представляет иерархию слабонарушенных блоков, которые контактируют друг с другом по широким зонам сгущения сравнительно непротяженных разрывов. Зонно-блоковая структура чехла отражает разломно-блоковую структуру фундамента. В его пределах большинство разломов являются сместителями магистрального типа, тогда как в чехле это зоны, внутренняя структура которых находится на ранних стадиях развития и представлена густой сетью трещин и разрывов 2-го порядка.
Строение одной и той же разломной зоны неоднородно, так как ее отдельные сегменты находятся на ранней или поздней стадии развития внутренней структуры, что связано с изначально неравномерным распределением деформаций и усугубляется реологической расслоенностью осадочного чехла. Разломные зоны в пластичных слоях (глины, аргиллиты) представлены сгущением мелких разрывов и трещин, что соответствует ранней стадии разрывообразования. В смежных менее податливых слоях (песчаники, алевролиты) разломная зона состоит из более длинных нарушений вплоть до появления сегментов магистрального сместителя, что является признаком перехода к поздней стадии разрывообразования.

Строение сети разломных зон определяется историей тектонического развития региона, в которой главные динамические обстановки отражают этапы тектогенеза, интенсивно проявляющиеся в смежных подвижных поясах. В случае присутствия в осадочной толще пластичных пород разломная структура чехла может осложняться гравитационным складко- и разрывообразованием, стиль которого зависит от серии локальных факторов.

Тектонофизические условия накопления и миграции углеводородов в осадочном чехле платформ определяются характером зонно-блоковой структуры, а также динамическими обстановками ее формирования и активизации на отдельных этапах тектогенеза. Разломные зоны, характеризующиеся в целом высокой плотностью и хаотичностью сети составляющих их разрывов 2-го порядка, являются каналами миграции углеводородов в сегментах с доминированием растяжения и экранами - в условиях преобладания сжатия. Блоки, напротив, отличаются низкой плотностью разрывной сети и ее системным характером, что в условиях пониженных напряжений является значимым фактором для формирования залежей и/или их наиболее продуктивных участков.

Закономерности, представленные выше, предопределяют неоднородную проницаемость платформенного чехла для флюидов и газа и, таким образом, могут быть использованы в плане разработки на новом уровне стратегических принципов разведки месторождений углеводородов со сложной структурой. Вместе с тем они относятся к категории наиболее общих и, как это было показано на примере Северо-Тамбейского месторождения, характеризуются многообразием проявлений, важных в плане практического приложения. Их углубленное понимание представляется возможным за счет опыта применения тектонофизического подхода к анализу накопленной на производстве, уникальной геолого-геофизической информации.

\section{7. БЛАГОДАРНОСТИ}

Авторы благодарны директору ИЗК СО РАН, чЛ.-корр. РАН Д.П. Гладкочубу за всестороннюю поддержку исследований на всех этапах их реализации, а также А.А. Дорошенко, О.М. Горскому, И.А. Пантелееву, А.В. Черемных, 
А.А. Боброву, Н.В. Мисюркеевой, И.А. Шелохову, Т.В. Касперской, А.А. Каримовой и И.К. Декабреву за помощь в сборе, обработке и первичной интерпретации фактического материала.

\section{8. ЛИТЕРАТУРА / REFERENCES}

Aarre V., Astratti D., Al Dayyni T.N.A., Mahmoud S.L., Clark A.B.S., Stellas M.J., Stringer J.W., Toelle B. et al., 2012. Seismic Detection of Subtle Faults and Fractures. Oilfield Review 24 (2), 28-43.

Astafiev D.A., Skorobogatov V.A., 2006. Tectonic Control of Oil and Gas Potential of Yamal Peninsula. Oil and Gas Geology 2, 20-29 (in Russian) [Астафьев Д.А., Скоробогатов Б.А. Тектонический контроль газонефтеносности полуострова Ямал // Геология нефти и газа. 2006. № 2. C. 20-29].

Basir H.M., Javaherian A., Yaraki M.T., 2013. Multi-Attribute Ant-Tracking and Neural Network for Fault Detection: A Case Study of an Iranian Oilfield. Journal of Geophysics and Engineering 10 (1), 015009. https://doi.org/ 10.1088/1742-2132/10/1/015009.

Bogoyavlensky V.I., Sizov O.S., Bogoyavlensky I.V., Nikonov R.A., Kargina T.N., 2019. Earth Degassing in the Arctic: Comprehensive Studies of the Distribution of Frost Mounds and Thermokarst Lakes with Gas Blowout Craters on the Yamal Peninsula. Arctic: Ecology and Economy 4 (36), 52-68 (in Russian) [Богоявленский В.И., Сизов О.С., Богоявленский И.В., Никонов Р.А., Каргина Т.Н. Дегазация Земли в Арктике: комплексные исследования распространения бугров пучения и термокарстовых озер с кратерами выбросов газа на полуострове Ямал // Арктика: экология и экономика. 2019. № 4 (36). С. 52-68]. http:// dx.doi.org/10.25283/2223-4594-2019-4-52-68.

Bokun A.N., 2009. Horizontal Shear Zones: Physical Modeling of Formation and Structure. Izvestiya, Physics of the Solid Earth 45 (11), 996-1005. https://doi.org/10.1134/ S106935130911007X.

Chernyshev S.N., 1983. Rock Fractures. Nauka, Moscow, 240 p. (in Russian) [Чернышев C.Н. Трещины горных пород. М.: Наука, 1983. 240 с.].

Engelder T., Gross M.R., 1993. Curving Cross Joints and the Lithospheric Stress Field in Eastern North America. Geology 21 (9), 817-820. https://doi.org/10.1130/00917613(1993)021\%3C0817:CCJATL\%3E2.3.CO;2.

Gabrielsen R.H., Braathen A., 2014. Models of Fracture Lineaments - Joint Swarms, Fracture Corridors and Faults in Crystalline Rocks, and Their Genetic Relations. Tectonophysics 628, 26-44. https: //doi.org/10.1016/j.tecto.2014. 04.022 .

Girshgorn L.Sh., Kabalyk V.G., 1990. Uplifted Sediment Cover above the Deep-Seated Circular Depressions in the Northern West Siberia. Soviet Geology 1, 57-63 (in Russian) [Гиршгорн Л.Ш., Кабалык В.Г. Поднятия чехла над глубинными кольцевыми депрессиями на севере Западной Сибири // Советская геология. 1990. № 1. С. 57-63].

Hancock P.L., Engelder T., 1989. Neotectonic Joints. GSA Bulletin 101 (10), 1197-1208. https://doi.org/10.1130/ 0016-7606(1989)101\%3C1197:NJ\%3E2.3.CO;2.
Khair H.A., Cooke D., Backé G., King R., Hand M., Tingay M., Holford S., 2012. Subsurface Mapping of Natural Fracture Networks; a Major Challenge to Be Solved. In: Case Study from the Shale Intervals in the Cooper Basin, South Australia. Proceedings of the Thirty-Seventh Workshop on Geothermal Reservoir Engineering (January 30 - February 1, 2012). Stanford University, California, USA, p. 1085-1092.

Khrenov P.M., Demin A.N., Taskin A.P. et al., 1977. Blind Transverse Faults of the Baikal Rift System. In: N.A. Logachev, N.A. Florensov (Eds), A Role of Rifting in the Geological History of the Earth. Nauka, Novosibirsk, p. 99-104 (in Russian) [Хренов П.М., Демин А.Н., Таскин А.П. и др. Скрытые поперечные разломы Байкальской рифтовой системы // Роль рифтогенеза в геологической истории Земли / Ред. Н.А. Логачев, Н.А. Флоренсов. Новосибирск: Наука, 1977. С. 99-104].

Kontorovich A.E., Eder L.V., 2015. A New Paradigm of the Development Strategy for the Mineral Resource Base of the Oil Producing Industry in the Russian Federation. Mineral Recourses of Russia. Economics and Management 5, 8-17 (in Russian) [Конторович А.Э., Эдер Л.В. Новая парадигма стратегии развития сырьевой базы нефтедобывающей промышленности Российской Федерации // Минеральные ресурсы России. Экономика и управление. 2015. № 5. С. 8-17].

Kontorovich V.A., 2009. The Meso-Cenozoic Tectonics and Petroleum Potential of West Siberia. Russian Geology and Geophysics 50 (4), 346-357. https://doi.org/10.1016/ j.rgg.2009.03.012.

Kurkin A.A., 2019. An Updated Overview of Oil and Gas Potential of the Eastern Yamal Based on Detailed Model of the Geological Development. PhD Thesis (Candidate of Geology and Mineralogy). Tyumen, 219 p. (in Russian) [Kypкин А.А. Уточнение перспектив нефтеносности Востока Ямала на основе детальной модели геологического развития: Дис. ... канд. геол.-мин. наук. Тюмень, 2019. 219 c.].

Kushnir D.G., 2016. Pre-Yenisei Area of Taimyr and Gydan Peninsulas - Deep Seated Geological Structure and Petroleum Potential Prospects. Petroleum Geology - Theoretical and Applied Studies 11 (1), 1-29 (in Russian) [Кушнир Д.Г. Глубинное геологическое строение и перспективы нефтегазоносности Приенисейской полосы Таймыра и Гыдана // Нефтегазовая геология. Теория и практика. 2016. T. 11. № 1. C. 1-29]. https://doi.org/10.17353/20705379/6_2016.

Lamarche J., Gauthier B.D.M., Ondicolberry G., Chatelée S., 2018. Fracture Corridors in Fold and Thrust Zone, Devonian Sandstones Icla Syncline (Bolivia). In: Proceedings of the Third EAGE Workshop on Naturally Fractured Reservoirs (February 5-7, 2018, Muscat, Oman). EAGE, p. 1-5. https:// doi.org/10.3997/2214-4609.201800022.

Leonov Yu.G., 1995. Stresses in the Lithosphere and Itraplate Tectonics. Geotectonics 6, 3-21 (in Russian) [Лeoнов Ю.Г. Напряжения в литосфере и внутриплитная тектоника // Геотектоника. 1995. № 6. С. 3-21].

Makarov V.I., Shchukin Yu.K., 1979. Blind Fault Activity Assessment. Geotectonics 1, 96-109 (in Russian) [Макаров В.И., 
Щукин Ю.К. Оценка активности скрытых разломов // Геотектоника. 1979. № 1. С. 96-109].

Nezhdanov A.A., 2004. Seismogeological Analysis of Oil and Gas Deposits in West Siberia for Predicting and Mapping of Non-Anticlinal Traps and HC Recourses. Brief PhD Thesis (Doctor of Geology and Mineralogy). Tyumen, $32 \mathrm{p}$. (in Russian) [Нежданов А.А. Сейсмогеологический анализ нефтегазоносных отложений Западной Сибири для целей прогноза и картирования неантиклинальных ловушек и залежей УВ: Автореф. дис. ... докт. геол.-мин. наук. Тюмень, 2004. 32 с.].

Nezhdanov A.A., Varyagov S.A., Ogibenin V.V., Smirnov A.S., Spodobaev A.A., 2012. Traces of Vertical HC Migration in the North of West Siberia. In: A Current State of a Theory of the Origin, Methods of Forecasting and Technologies for Search of Deep Oil. $1^{\text {st }}$ Kudryavtsev Readings. Proceedings of the All-Russian Conference on Deep Oil Genesis (October 22-25, 2012). CGE, Moscow, p. 323-328 (in Russian) [Heжданов А.А., Варягов С.А., Огибенин В.В., Смирнов А.С., Сподобаев А.А. Следы вертикальной миграции УВ на севере Западной Сибири // Современное состояние теории происхождения, методов прогнозирования и технологий поисков глубинной нефти. 1-е Кудрявцевские чтения: Материалы Всероссийской конференции по глубинному генезису нефти (22-25 октября 2012 г.). М.: ЦГЭ, 2012. С. 323-328].

Osokina D.N., Tsvetkova N.Yu., 1979. A Method for Modeling Local Stress Fields near Tectonic Faults and in Earthquake Sources. Stress and Deformation Fields in the Lithosphere. Nauka, Moscow, p. 139-162 (in Russian) [Осокина Д.Н., Цветкова Н.Ю. Метод моделирования локальных полей напряжений в окрестностях тектонических разрывов и в очагах землетрясений // Поля напряжений и деформаций в литосфере. М.: Наука, 1979. С. 139-162].

Ozkaya S.I., Richard P.D., 2006. Fractured Reservoir Characterization Using Dynamic Data in a Carbonate Field, Oman. SPE Reservoir Evaluation and Engineering 9 (3), 227-238. https://doi.org/10.2118/93312-PA.

Pedersen S.I., Randen T., Sonneland L., Steen O., 2002. Automatic Fault Extraction Using Artificial Ants. In: Proceedings of the 72nd SEG Annual Meeting (October 6-11, 2002, Salt Lake City). Society of Exploration Geophysicists, USA, p. 512-515. https://doi.org/10.1190/1.1817297.

Podurushin V.F., 2011. Tectonic Structure of the Foundation and its Impact on the Development of Gas Potential of the Yamal Peninsula. Vesti Gazovoy Nauki 3 (8), 65-72 (in Russian) [Подурушин В.Ф. Тектоника фундамента и ее влияние на формирование газового потенциала полуострова Ямал // Вести газовой науки. 2011. № 3 (8). C. 65-72].

Podurushin V.F., 2014. Tectonics of the Geophysical Mezoval (North of the Western Siberia). Vesti Gazovoy Nauki 3 (19), 82-88 (in Russian) [Подурушин В.Ф. Тектоника и особенности нефтегазоносности геофизического мезовала (север Западной Сибири) // Вести нефтегазовой науки. 2014. № 3 (19). С. 82-88].

Radkevich E.A., Tomson I.N., Gorlov N.V., 1956. On Regional Excessive Fracture Belts and Belts and Zones. Soviet
Geology 58, 170-185 (in Russian) [Радкевич E.А., Томсон И.Н., Горлов Н.В. О региональных поясах и зонах повышенной трещиноватости // Советская геология. 1956. № 58. C.170-185].

Rats M.V., Chernyshev S.N., 1970. Fracturing and Properties of Fractured Rock. Nedra, Moscow, 164 p. (in Russian) [Рац М.В., Чернышев С.Н. Трещиноватость и свойства трещиноватых горных пород. М.: Недра, 1970. 164 с.].

Seminsky K.Zh., 2003. Internal Structure of Continental FaultZones. Tectonophysical Aspect. GEO, Novosibirsk, 244 p. (in Russian) [Семинский К.Ж. Внутренняя структура континентальных разломных зон. Тектонофизический аспект. Новосибирск: Гео, 2003. 244 с.].

Seminsky K.Zh., 2008. Hierarchy in the Zone-Block Lithospheric Structure of Central and Eastern Asia. Russian Geology and Geophysics 49 (10), 771-779. https://doi.org/10. 1016/j.rgg.2007.11.017.

Seminsky K.Zh., 2014. Specialized Mapping of Crustal Fault Zones. Part 1: Basic Theoretical Concepts and Principles. Geodynamics \& Tectonophysics 5 (2), 445-467 (in Russian) [Семинский К.Ж. Спецкартирование разломных зон земной коры. Статья 1: Теоретические основы и принципы // Геодинамика и тектонофизика. 2014. Т. 5. № 2. C. 445-467]. https://doi.org/10.5800/GT-2014-5-2-0136.

Seminsky K.Zh., 2015. Specialized Mapping of Crustal Fault Zones. Part 2: Main Stages and Prospects. Geodynamics \& Tectonophysics 6 (1), 1-43 (in Russian) [Семинский К.Ж. Спецкартирование разломных зон земной коры. Статья 2: Основные этапы и перспективы // Геодинамика и тектонофизика. 2015. Т. 6. № 1. С. 1-43]. https://doi.org/ 10.5800/GT-2015-6-1-0170.

Seminsky K.Zh., Sankov V.A., Ogibenin V.V., Burzunova Yu.P., Miroshnichenko A.I., Gorbunova E.A., Gorlov I.V., Smirnov A.S., Vakhromeev A.G., Buddo I.V., 2018. Tectonophysical Approach to the Analysis of Geological and Geophysical Data on Gas-Condensate Deposits with the Complex Platform Cover. Geodynamics \& Tectonophysics 9 (3), 587-627 (in Russian) [Семинский К.Ж., Саньков В.А., Огибенин В.В., Бурзунова Ю.П., Мирошниченко А.И., Горбунова Е.А., Горлов И.В., Смирнов А.С., Вахромеев А.Г., Буддо И.В. Тектонофизический подход к анализу геолого-геофизических данных на газоконденсатных месторождениях со сложным строением платформенного чехла // Геодинамика и тектонофизика. 2018. Т. 9. № 3. С. 587-626]. https: //doi.org/10.5800/GT-2018-9-3-0364.

Sherman S.I., Bornyakov S.A., Buddo V.Yu., 1983. Areas of Dynamic Influence of Faults (Modelling Results). Nauka, Novosibirsk, 112 p. (in Russian) [Шерман С.И., Борняков С.А., Буддо В.Ю. Области динамического влияния разломов (результаты моделирования). Новосибирск: Наука, 1983. 112 с.].

Silva S.C., Marcolino C.S., Lima F.D., 2005. Automatic Fault Extraction Using Ant Tracking Algorithm in the Marlim South Field, Campos Basin. In: Proceedings of the 2005 SEG Annual Meeting (November 6-11, 2005, Houston). Society of Exploration Geophysicists, USA, p. 857-861.

Sim L.A., 2013. Overview of the State of Knowledge on Paleotectonic Stresses and Their Implications for Solution 
of Geological Problems. Geodynamics \& Tectonophysics 4 (3), 341-361 (in Russian) [Сим Л.А. Краткий обзор состояния изученности палеотектонических напряжений и их значение для решения геологических задач. Геодинамика и тектонофизика. 2013. Т. 4. № 3. С. 341361]. https://doi.org/10.5800/GT-2013-4-3-0105.

Singh S.K., Abu-Habbiel H., Khan B., Akbar M., Etchecopar A., Montaron B., 2008. Mapping Fracture Corridors in Naturally Fractured Reservoirs: An Example from Middle East Carbonates. First Break 26 (5), 59-63. https://doi.org/ 10.3997/1365-2397.26.1119.27999.
Sobornov K.O., Yakubchuk A.S., 2006. Plate-Tectonic Development and Formation of Northern Euroasia Basins. Oil and Gas Geology 2, 10-18 [Соборнов К.О., Якубчук А.С. Плитотектоническое развитие и формирование нефтегазоносных бассейнов Северной Евразии // Геология нефти и газа. 2006. № 2. C. 10-18].

Souque C., Knipe R.J., Davies R.K., Jones P., Welch M.J., Lorenz J., 2019. Fracture Corridors and Fault Reactivation: Example from the Chalk, Isle of Thanet, Kent, England. Journal of Structural Geology 122, 11-26. https://doi.org/10. 1016/j.jsg.2018.12.004. 